\title{
TOWARDS A SYNDICALIST INTERNATIONAL: THE 1913 LONDON CONGRESS ${ }^{1}$
}

Although identified above all with the French Confédération Général $d u$ Travail prior to the First World War, revolutionary syndicalism had become an international movement by 1914, when various labour organizations in Europe, North and South America, and Australasia espoused its doctrines or the kindred doctrines of industrial unionism. The desire to establish durable international bonds between these revolutionary organizations had grown steadily, especially in Europe, where by 1912 organized syndicalist bodies existed in France, Holland, Germany, Sweden, Denmark, Britain, Belgium, Spain and Italy. The congress held in London in the autumn of 1913 represented the first effort to create a vehicle of syndicalist internationalism. But the congress and the debate surrounding it demonstrated not only that syndicalists were not in accord on international tactics, nor on national tactics, but also that the deepest cleavage on the question of international strategy was that dividing the CGT from most syndicalist organizations in other countries.

Because they insisted upon the autonomy of labour, the international ideal of the syndicalists remained that of the First International, which they viewed as a genuinely revolutionary International imbued with a libertarian spirit. They placed no faith in the Second International, which had early imposed a pledge of political action and in 1896 had expelled the anarchists. The International Secretariat of National Trade Union Centres, on the other hand, was a strictly labour organization. Its exclusivist and reformist character, however, led many syndicalists to view the ISNTUC's contribution to proletarian progress as more pernicious than beneficial.

The Secretariat assumed a practical and moderate character from the beginning. In deference to the Second International, the Germans of the

\footnotetext{
1 All dates cited refer to the year 1913, unless otherwise specified.
} 
social-democratic Freie Gewerkschaften consented only to a meeting of the leading officers of the national trade-union organizations in the conferences preceding the creation of the ISNTUC, the first of which was held in Copenhagen, where Scandinavian, British, French, Belgian and German officials assembled in 1901. This system of representation was carried over into the biennial conferences of the Secretariat when it was formally created in 1903. Between 1902 and 1903 the Freie Gewerkschaften had acted at their own expense as an informal international union centre. German initiative was rewarded in 1903, when Berlin was selected as the seat of the new organization and Carl Legien appointed irternational secretary, a position he held throughout the pre-war period. The ideal of union organization which the ISNTUC soon came to reflect - that of a highly centralized, dues-conscious national centre working closely with the socialist party - was that which the German organization embodied par excellence. Most affiliates shared this ideal. The ISNTUC grew steadily from a membership of two million in 1905 to over seven million in 1913, when nineteen countries adhered.

The practical and reformist commitment of the new organization was underscored as early as 1904. Legien opposed the request of the CGT that antimilitarism and the general strike be placed on the agenda of the Amsterdam conference scheduled for 1905, replying that such questions lay beyond the province of the conference. The majority of the trade-union centrals supported him. The response to this disagreement was two-fold: on the one hand, the CGT boycotted the 1905 conference; on the other, the ISNTUC adopted a German resolution in Amsterdam whereby it excluded from its consideration "all theoretical questions and those which concern the tendencies and tactics of the trade-union movement in the individual countries". ${ }^{2}$ It declared its concerns to be the more practical ones of fostering relations between national union centres, collecting uniform labour statistics, and facilitating mutual support. When the French boycotted the 1907 Christiania conference because their agenda submissions had again been refused, the ISNTUC demonstrated its orientation even more clearly by unanimously accepting a resolution indicating its own support for the Second International and, in effect, formally censuring the anti-political attitude of the French. Following the Christiania conference the CGT altered its tactics. Its delegates attended the 1909 conference, where they advocated transforming the ISNTUC conferences of a few select delegates into trade-union congresses in which unionists

2 Quoted in Joh. Sassenbach, Fünfundzwanzig Jahre internationale Gewerkschaftsbewegung (Amsterdam, 1926), pp. 17-18. 
could discuss not only the practical questions of organized labour, but the larger issues barred from the ISNTUC meetings as well. This constituted a return to the policy unsuccessfully advocated by the Dutch of the Nationaal Arbeids-Secretariaat, with French support, at the 1902 Stuttgart conference. The proposal of the CGT was turned back in 1909, as it was in Budapest in 1911.

By then the Secretariat's exclusive devotion to reformist concerns and its support for the Second International had brought it into disrepute with " many of the syndicalists of Europe. Its character could be altered only if its structure were altered, but this the ISNTUC steadfastly refused to do. By admitting a single trade-union central from each country, the national syndicalist organizations as minority movements were barred from membership, and their nation represented exclusively by their reformist rivals. By 1907 the only revolutionary member was the CGT, the NAS having withdrawn in protest. The libertarian organizations were not merely barred, for the Secretariat employed its conferences and its annual report to hurl accusations at them. In terms of the spread of syndicalist organizations, by 1912 the syndicalists could view the preceding years as a period of international progress. But those organizations were confronted by hostile reformist unions within their frontiers, and were without ties abroad. Already in 1909 the NAS had called attention to the isolation of the revolutionary unions, and had asked how long it could be permitted to continue. "We are waiting for France, we know that, but that may well go on so long that in the mean time major interests are neglected."3 By 1913 the syndicalists were ready to act.

The appeal for an international syndicalist congress came simultaneously from Britain and Holland. The November 1912 London and Manchester conferences of the Industrial Syndicalist Education League instructed the League to organize an international congress. The NAS had created a committee charged with the same task, which in February 1913 issued a circular over the signature of Gerrit van Erkel calling for a syndicalist congress. The secretary of the ISEL, Guy Bowman, published the British invitation the same month. The thrust of the two appeals was nearly identical. Both lamented the lack of effective supra-national solidarity occasioned by the absence of an international syndicalist organization. Both damned existing international bodies as antithetical to the interests and goals of syndicalists. Of the Second International the British invitation declared:

We cannot be rendered impotent by having our international relations 3 De Arbeid, 27 November 1909. 
conducted through a body that exacts a pledge of parliamentarism and is composed of glib-tongued politicians who promise to do things for us, but cannot even if they wanted to. We must meet as Syndicalists and Direct Actionists to prepare and develop our own movement for economic emancipation free from the tutelage of all politicians.

Both rejected the ISNTUC, from which, van Erkel asserted, "toute propagande révolutionnaire [...] est exclue systématiquement". Bowman observed that it would make little difference if the ISNTUC permitted the presentation of resolutions on such questions as industrial sabotage and antimilitarism, "for the whole of the permanent officials are politicians; most of the delegates are conservative if not absolute reactionaries; and the whole business is controlled by Social Democrats". ${ }^{4}$ While the British called for a congress to be held in London in May, the Dutch circular initiated a canvass of opinion on whether an assembly should be convened in the autumn and, if so, where.

The responses were not long in coming. The Germans of the Freie Vereinigung deutscher Gewerkschaften (FVDG) expressed ardent support; the summonses were warmly received elsewhere as well, including Austria, Sweden, Denmark, Italy and Spain. ${ }^{5}$ A number of organizations, however, shared the opinion of Christiaan Cornelissen, the editor of the Bulletin

4 Bowman in The Syndicalist and Amalgamation News (hereafter SAN), February; van Erkel in Bulletin International du Mouvement Syndicaliste, 16 February. This issue of the Bulletin reproduced much of the Dutch circular and the whole of the British invitation. The entire Dutch circular appeared in De Nederlandsche Zeeman, 1 March.

5 Die Einigkeit (Germany), 22 February; Wohlstand für Alle (Austria), 26 February; Syndikalisten (Sweden), 1 March; Solidaritet (Denmark), 1 March; L'Internazionale (Italy), 1 March: Tierra y Libertad (Spain), 24 February. In the United States both the Industrial Workers of the World and the Syndicalist League of North America welcomed the congress proposal. William Z. Foster's SLNA identified with the CGT, tended to favour craft unionism, and opposed the dual unionism of the IWW, with which Foster had broken in 1912. Foster promoted the congress, in which he hoped the SLNA would be represented. The Syndicalist (Chicago), 1 February. But the SLNA was short-lived and The Syndicalist itself disappeared in September 1913. The IWW's Industrial Worker (Spokane, Wash.) identified syndicalism above all with craft unionism and contrasted with it the IWW's industrialism: "The I.W.W. is not a syndicalist organization, though many regard it as such. It is an industrial union. [. . . In international affiliations the I.W.W. is more closely allied with the revolutionary syndicalists than any other body. [...] still it is well to understand from the outset that the I.W.W. represents a higher type of . revolutionary labor organization than that proposed by the syndicalists." ( 9 January) Taking note of the congress proposal, the Industrial Worker on 3 April again remarked upon the superiority of the IWW's industrialism, but recommended the congress, adding: "let its most important work be the formation of a connecting link between the revolutionary syndicalists and industrialists of all countries." The Industrial Worker dismissed the ISNTUC as a "farce", but observed that the official position of the IWW on the London congress would have to await its annual convention in September. 
International du Mouvement Syndicaliste, that the May date proposed by the British was impractical. While he viewed the congress as urgently required, Cornelissen cautioned that an assembly too hastily convened would not benefit the syndicalists, but would squander their efforts and possibly give rise to the charge that "dans notre mouvement révolutionnaire, l'esprit organisateur fait trop défaut pour la préparation matérielle d'un congrès". 6

From one country, however, assent to the congress proposal was not forthcoming, for in France the Dutch and British invitations received a chilly reception. Pierre Monatte raised a critical voice that proved to be the opening salvo in a sustained controversy between the advocates of the congress and the policy-makers of the CGT. The French maintained their resistance to the congress proposal to be motivated solely by interests of labour unity. Their participation in a syndicalist congress could only mean the abandonment of the CGT's goal of revolutionizing the ISNTUC from within. The majority of organized workers were affiliated with the ISNTUC and the attention of the syndicalists ought to be directed to them. To embark upon a separate international course was a divisive enterprise; it could only jeopardize the workers' movement as a whole.

The controversy demonstrated that the respective arguments on international policy were conditioned above all by national perspectives. For most non-French syndicalists, locked in bitter struggle with their domestic rivals in the large reformist unions, the leaders of which were the same functionaries who controlled the ISNTUC, the CGT's expectation of "revolutionizing" the Berlin Secretariat from within was, at best, unrealistic. For them it was evident that the reformists valued unity, nationally and internationally, only on their own terms. The Secretariat secured a degree of international unity only by excluding dissidents, by refusing to entertain any questions of revolutionary import, and by supporting the Second International. The ISNTUC, moreover, had publicly censured the policy of the CGT, and it was dominated, as were the international trade federations, by the Germans, who had made a slogan of the phrase "The General Strike is General Nonsense". Did not the ideals embodied in the Berlin Secretariat constitute a greater threat, despite

\footnotetext{
${ }^{6}$ Bulletin, 16 February. At the International Anarchist Congress in Amsterdam in 1907 the merits of revolutionary syndicalism had been discussed in a lively debate between the veteran Italian anarchist Errico Malatesta and the young French militant Pierre Monatte. The congress gave rise both to a short-lived anarchist bulletin and to the more durable Bulletin of Cornelissen, a Dutch militant also active in the French movement.
} 
French claims, to the CGT than the latter did to the ISNTUC? To most non-French syndicalists the ISNTUC was a certain barrier to working-class progress; the barrier could not be scaled, as the French believed, but had to be circumvented. By meeting in their own congresses they would simultaneously begin the task of circumventing the ISNTUC and of escaping the domestic isolation which their ongoing struggles with the reformists imposed upon them. A need for self-assertion and legitimization underlay the drive to break this isolation. As revolutionaries, the syndicalists obviously sought no accommodation with their reformist rivals, who dominated the national and international labour scene and by whom they were constantly vilified. But to identify their respective movements with an organized international revolutionary movement would confer dignity, status and recognition upon them, and be an aid in the struggle to expand them. The same need for self-assertion and legitimization underlay the desire to identify syndicalism as an international movement in contradistinction to a peculiarly French form of organization and practice transplanted into alien soil beyond France.

All foreign syndicalists rejected French claims that the only international policy open to the CGT was to work within the ISNTUC. Some pointed out that there was no contradiction in working both within and without the Secretariat for the establishment of a genuine workers' International. Others saw the continued presence of the CGT in the ISNTUC as a contravention of syndicalist doctrine, which viewed the spread of its principles and practice as a movement from below and not from above, and certainly not through the select conferences of the Berlin Secretariat. By clinging to the ISNTUC and refusing to join the effort to establish a basis for international syndicalist accord, French conduct appeared in the eyes of some of their foreign counterparts as lamentably arriviste. Did the CGT itself seek legitimization and recognition, but by accommodating itself to the dominant international union movement of the reformists? Before the pre-congress debate drew to a close, the question would arise whether the international policy of the CGT did not demonstrate that French syndicalism had lost much of its revolutionary impetus.

This charge was not without substance. Though the French declared their arguments to rest upon the in terests of trade unionism throughout the world, their opposition to the congress was also rooted in a national perspective. The CGT had no large reformist union organization with which to compete in France, and there was some justification to the charge that the French consistently underestimated the enormous difficulties of pursuing a syndicalist campaign within established reformist unions. But reformist elements constituted a substantial minority within the CGT itself, 
and the moderates had their own strongly held views on international policy. At the 1908 CGT congress in Marseille the reformists rejected the CGT's international strategy. They argued for a resumption of international relations and urged the CGT's return to the ISNTUC conferences, even if they were only meetings of officials. The reformists indicated, moreover, that it was not impossible that the international issue could bring the CGT to schism. ${ }^{7}$ The policy-makers of the CGT could never thereafter ignore the fact that the international policy of the CGT bore 'serious domestic implications. The conciliatory resolution adopted by the congress nearly paralleled that supported by the reformists. The demand that antimilitarism and the general strike be entered on the ISNTUC agenda was dropped. The CGT would return to the international meetings if the ISNTUC placed the question of holding trade-union congresses, instead of conferences of officials, on its agenda. The Secretariat accepted the CGT's agenda submission and the French, in turn, agreed that the 1909 ISNTUC conference be held in Paris. At the conference, Léon Jouhaux, secretary of the CGT, proposed that the meetings be converted to tradeunion congresses, but the French withdrew the proposal when the foreign delegates uniformly opposed it. However unlikely that the ISNTUC would support such an initiative - it had categorically rejected it long before the CGT's revised strategy had the advantage of meeting the demands of the reformist elements within it who insisted upon French participation in the Berlin Secretariat.

Though in 1909 some cégétistes protested this concession to the reformists, and revolutionary unionists both within the ranks of the CGT and outside France contemplated a new and distinctly radical departure in international tactics, the strategy of the CGT remained unchanged. ${ }^{8}$ For

7 The general debate on the international question can be followed in XVIe Congrès National Corporatif (Xe de la C.G.T.) (Marseille, 1909), pp. 60-79, 153-66. Intimations of schism were however avoided on the congress floor. A letter of Alphonse Merrheim to Monatte, 7 October 1908, is illuminating in this respect. Merrheim was chiefly responsible for the resolution accepted at Marseille. In discussing the work of the committee charged with dealing with the international question, he wrote: "Niel, poussé à bout, a été amené à déclarer que si nous ne voulions pas assister aux conférences, avant deux ans, il y aurait comme [en] Hollande deux confédérations, une adhérente au Bureau International, l'autre pas. Je lui ai demandé si c'était au collimateur. Il n'a répondu ni oui, ni non, et Guérard a protesté en disant qu'il n'irait pas jusque-là. Coupat s'est tu. Serait-ce la scission qui commencerait?" Quoted in Christian Gras, Alfred Rosmer (1877-1964) et le mouvement révolutionnaire international (Paris, 1971), p. 85.

${ }^{8}$ Léon Robert, a participant in the Marseille debates, criticized the decision made there and called for a change in La Voix du Peuple, 26 September - 3 October 1909. Travailleur du Bâtiment pondered the creation of a separate International grouping revolutionary unionists in May 1909. See also Les Temps Nouveaux, 23 July 1910. The Dutch 
during 1908-09 an international policy had, in effect, begun to coalesce which would satisfy the diverse ideological currents within the CGT. The CGT saw its international future within the ISNTUC, which it would eventually revolutionize; by means of this formula most reformists were placated by the presence of the CGT in the ISNTUC, most revolutionaries by its professed purpose there. Few foreign syndicalists recognized the domestic imperatives which kept the CGT tied to the Secretariat; thus many of them were baffled when the CGT persisted in its fruitless efforts to transform the ISNTUC conferences into genuine trade-union congresses, but attacked the efforts of their fellow syndicalists to initiate such congresses outside the Secretariat. By 1913, when the lack of ideological cohesion within the CGT had become more pronounced, French international policy had rigidified. By then the CGT was in a state of crisis. Its membership had peaked in 1911 and had been declining since, although the number of unionized workers in France increased. The erosion of popular support strengthened the hand of the reformists, who, noting that the traditionally more radical federations had suffered the greatest membership losses, criticized the organizational weakness of the CGT and its relative lack of concern with the day-to-day issues of trade unionism.

The reformists were aided by a widening split in the revolutionary wing of the CGT. The orthodox revolutionaries continued to defend the entire gamut of the traditional revolutionary concerns of French syndicalism, and attached more importance to the revolutionary zeal of the workers than to membership figures, though their spokesmen in positions of leadership were gradually being replaced by representatives of what might be called the "revisionist" syndicalists. The latter had little use for talk of violence and the general strike, which they viewed as evidence of organizational weakness. Antimilitarism and antipatriotism had their place in the labour movement, but the CGT had devoted too much attention and energy to them. Organization was the prime concern of the revisionists. They saw organizational reform as the only means of countering the increasing

broached the same subject in De Arbeid, 27 November 1909. The French sought to dissuade them. In La Vie Ouvrière, 20 December 1909, p. 336, Monatte argued unenthusiastically that the American Federation of Labor, which had just entered the ISNTUC, could induce the Germans to transform the latter into a genuine workers' International. But two years later the CGT delegates supported a bid of the IWW to unseat the AFL in the ISNTUC. At the 1911 Budapest conference, William Foster, the IWW delegate, argued that the AFL was a collaborationist organization and unfit to prosecute the class struggle. Only the French supported the IWW in the conference, which decided to retain the AFL and bar the IWW. Paul Brissenden, The IWW: A Study in American Syndicalism (New York, 1957), pp. 273-75. 
concentration of French capital. Economic reality, they maintained, dictated a restructuring of the labour movement. They valued large union organizations with a disciplined membership and urged that the CGT adopt a more centralist policy. In this they stood in direct opposition to the economic decentralization-and spontaneous action urged by traditional cégétistes. The position of the revisionists, in short, had many points of contact with that of the reformists. But unlike the latter, they repudiated political action and they remained revolutionary in their goals; they had no desire to see the labour movement integrated into French society. The revisionists were caught up in a dimly perceived paradox: while their faith in revolutionary principles remained unshaken, the new labour strategy they believed necessitated by the realities of industrial change in France implied a recognition of reformist practices. Despite their own convictions, they were contributing to the growth of a reformist attitude which the CGT's later collaboration with the state in the Union Sacrée during the war would accentuate. ${ }^{9}$

Confronted with a domestic crisis which had thwarted its growth and had accentuated the ideological cleavages within the CGT, the Dutch and British initiatives appeared at the critical time for the French. The CGT had little choice but to cling all the more tightly to an international policy which had shown that it commanded a consensus among reformists and revolutionaries. The task of defending the CGT's policy was taken up chiefly by the internationally-minded noyau grouped around Monatte's $\mathrm{La}$ Vie Ouvrière. Markedly revisionist in outlook, the Vie Ouvrière group were loath to admit that the CGT's international policy owed anything to the reformists. For the revisionists had made the policy hammered out in 1908-09 their own. By 1913 they viewed it, in effect, as an extension of their domestic policy. While the domestic movement had to be restructured along more highly organized, unified and disciplined lines, and yet retain a revolutionary commitment, the degree of organization achieved in the international movement had to be preserved and extended, but given a revolutionary spirit which it conspicuously lacked. In short, the ISNTUC had to be transformed into a revolutionary forum: this was the task of the CGT. Though convinced that this tactic was both correct and revolutionary, the very scorn with which the Vie Ouvrière group dismissed the suggestion that the CGT's policy owed anything to reformist pressures indicated that this criticism had touched a sensitive nerve. And while $L a$ Vie Ouvrière naturally chose to cast its arguments in terms of international

9 The crisis of the CGT and the divisions within it are discussed in Michael S. DeLucia, "The Remaking of French Syndicalism, 1911-1918: The Growth of the Reformist Philosophy" (Ph.D. dissertation, Brown University, 1971). 
labour unity, when it discussed the dangers of national schisms it always spoke in the abstract; it manifested a palpable disinclination to discuss the threat the congress proposal bore for the fragile unity of the French movement itself. Others in the CGT exercised less reserve. ${ }^{10}$ Some foreign critics saw in the arguments of La Vie Ouvrière a divorce between practice and principles and attributed it to a form of hypocrisy, while the Vie Ouvrière group, in their turn, tended to view the attitude of the congress supporters as a species of revolutionary immaturity.

\section{III}

The chief concern of the French was not simply that a syndicalist congress be held, but that it give rise to a revolutionary labour International. To judge by their appeals, this larger aim was the express intent of the Dutch and the implicit goal of the British. On this assumption, Monatte attacked the invitations. It was impossible for the French "de partager le point de vue de nos camarades hollandais". Monatte devoted rather more attention to the British proposal. "Ce que nous regrettons surtout c'est l'initiative de nos camarades anglais. Ils sont en train de courir à une oeuvre vaine". The domestic tactic of the British syndicalists of pursuing their propaganda within existing labour bodies, Monatte claimed, was correct. He believed the older organizations had been singularly rejuvenated in recent years by this tactic. The British syndicalists ought to pursue an international policy consistent with their domestic policy by seeking to convert and rejuvenate the ISNTUC rather than contemplating the creation of a rival international organization. The British General Federation of Trade Unions could in a few years be won over to the idea of a true workers' international congress, and with the aid of the CGT, would make it prevail in the ISNTUC. If the ISEL "prend une autre voie, elle commettra une grave faute de tactique qui pèsera longtemps sur le développement du syndicalisme en Europe et par le monde."11

Not all proponents of the congress, however, assumed its purpose to be the creation of a new International. In addition to the Dutch and the British, the Germans of the FVDG early signalled the importance they attached to this question by proposing it as a chief item on the congress agenda. "The creation of an autonomous Syndicalist International", Die Einigkeit declared, "is a necessity for the self-preservation and onward

10 Thus A. Luquet of the Fédération des Coiffeurs de France argued that the international endeavours of the foreign syndicalists were not to be welcomed because their success would lead to opposition to the ISNTUC, which ir turn would lead to a serious rupture within the ranks of the organized workers of France. L'Humanité, 4 March.

11 La Vie Ouvrière (hereafter VO), 20 February, p. 254. 
development of syndicalism."12 Cornelissen, on the other hand, asked French critics how they could know that the French unions which might participate would wish to establish a new International; that they would not consider international congresses as sufficient links between syndicalist organizations? Other syndicalists welcomed the proposed congress as a means of breaking the isolation in which their organizations found themselves. Alceste De Ambris of the Unione Sindacale Italiana denied the goal of the congress to be the establishment of a new Secretariat in competition with that of Berlin for a simple reason: Secretariats were useless. But the international meetings, the congresses themselves, were important. Only by means of them could the USI escape from the isolation imposed upon it. On the same grounds, a more impassioned response to French resistance came from Belgium. L. Wolter of Liège argued that Monatte failed to appreciate the situation in countries like Belgium and Germany, where the syndicalists were forced to withdraw from socialdemocratic unions, "car là on entravait leur besogne d'éducation, on étouffait systématiquement la liberté de penser", and to the struggle against "la mauvaise foi, les calomnies intéressées" of social-democratic labour leaders. Beleaguered within the labour movement in their own countries, the syndicalists were also isolated in the international movement by the very statutes of the ISNTUC. This isolation could be broken if the French, the "aînés" from whom the other syndicalists "ont puisé tout le meilleur de leur être", would join and invigorate the proposed congress. By refusing to participate, the French were failing in a duty:

Est-ce ainsi que des frères aînés doivent agir? Alors que vous devriez nous aider dans notre oeuvre d'épuration du mouvement ouvrier, vous nous rejetez dédaigneusement; mieux que cela, vous nous ignorez.

Vraiment, votre attitude en cette occasion me fait songer à ces bourgeois arrivés qui ne reconnaissent plus leurs camarades de jeunesse moins habiles ou moins bien servis par les circonstances.

The day would come, Wolter warned, when the forces of reaction embodied in the social-democratic unions of neighbouring countries would become a permanent threat to the ideal of social emancipation which inspired the French movement. But the French position remained unchanged. The majority of workers would not be represented in a syndicalist gathering; the assembly would be a congress only in name. Were the CGT to abandon the ISNTUC, Monatte argued, the latter would continue to hold its conferences but, with the radical elements removed, the inter-

${ }^{12}$ Die Einigkeit, 5 April. 
national interests of the workers would no longer be furthered there. ${ }^{13}$

The publication of French disapproval did nothing to reduce the persistence of the British. In reply, Bowman declared that the revolutionary minorities could find international expression only in a syndicalist congress. Fears that such a congress would lead to the destruction of workers' unity were unfounded, for that valued unity scarcely existed yet; the syndicalist organizations, moreover, would know how to maintain unity without abandoning their right to discuss working-class problems in their own assemblies. As for French resistance, Bowman professed optimism: "We know how our French comrades will act when the time draws nearer." In the face of French opposition, Tom Mann, President of the ISEL, took another tack. Declaring frankly that not merely a congress, but an international syndicalist Secretariat was needed, Mann not only urged Gallic participation, but proposed that the French unions themselves should sponsor the congress, to which British syndicalists would happily adhere. "Une glorieuse occasion de rendre un éminent service à la cause du prolétariat universel s'offre maintenant à nos camarades de France."14 Since Mann and Bowman had early personal confirmation of imminent French resistance to the proposed congress, ${ }^{15}$ it may well be that their arguments were designed less to persuade the leaders of the CGT and the national federations than to secure support from the local union organizations of France.

Cornelissen adopted this approach explicitly and invoked the syndicalist principle of autonomy in support of it. Before the French had publicly uttered a word on the invitations, Cornelissen, himself involved actively in the French movement, had called attention to its uniqueness and noted the difficulties given the CGT's position in the ISNTUC, for the former to convene a syndicalist congress. But the national federations and the Bourses du Travail were not confronted with the same problem. Though affiliated with the CGT, they were autonomous, and some of them, Cornelissen added hopefully, were "assez révolutionnaires dans leur action pour croire utile de venir en aide aux autres nations et pour ne pas s'abstenir du congrès". ${ }^{16}$ Once French opposition had become public, ${ }^{13}$ Cornelissen in Bulletin, 9 March; De Ambris and Wolter (mistakenly called Walter) in VO, 5 April, pp. 404-06; Monatte ibid., 20 March, pp. 377-78.

14 Bowman in SAN, March-April; Mann in VO, 5 April, pp. 434-35.

15 Alfred Rosmer had attended the London ISEL conference on behalf of $L a$ Bataille Syndicaliste and as a fraternal delegate of the CGT. He and Léon Jouhaux had also been present at the Manchester conference. SAN, December 1912. The proposal that the ISEL organize an international congress was first endorsed at both conferences. At that time Jouhaux and Rosmer apparently told Mann and Bowman that neither the CGT nor its member federations could be represented at such a congress. VO, 5 September, p. 267. ${ }^{16}$ Bulletin, 8 December 1912. 
Cornelissen responded by placing even greater emphasis upon the principle of union autonomy: "Mais le mouvement syndical français est-il, oui ou non, organisé sur la base de l'autonomie des Unions locales et régionales?" The unions should be permitted to make their own decisions and detractors from the proposal ought not "agiter tout de suite des épouvantails qui pourraient provoquer une prévention injustifiée contre le Congrès international". ${ }^{17}$ Cornelissen also applied the argument of autonomy on an international level in relation to the CGT's role in the 'ISNTUC. He rejected French claims that there was a conflict for the CGT in working both within and without the ISNTUC for the creation of a workers' international congress. On its own principles, the CGT should work for the realization of a syndicalist congress. It could do so even while continuing its propaganda within the reformist Secretariat. Monatte considered these two courses of action incompatible, but what then becomes of "l'autonomie des organisations nationales dans le secrétariat de Berlin si elles n'ont pas le droit de travailler en dehors pour leurs propres conceptions?"'18

These arguments and approaches, intended in part to convince the leaders of French syndicalism and in part to appeal to the local organizations, made little impact upon the former. It was simply a fact, Monatte observed, that in other countries the national syndicalist organizations could not adhere to the ISNTUC, but the CGT could and did adhere, which made its situation crucially different. It sought to realize a true workers' International where genuine labour congresses could be held, even if the syndicalists would be in a minority there. Do you not believe, Monatte asked, "que nous avons quelque raison de nous demander si notre participation à un congrès syndicaliste et à un secrétariat syndicaliste ne nous fera pas tourner le dos au grand but que nous nous sommes fixé?"19

Despite French disapproval the congress movement gained momentum. There remained the questions of determining its date and venue. The Germans appealed to the British to endorse an autumn congress to be held in Holland. Though willing to alter the date of the congress, the British resisted abandoning London as its site. Concurring with objections to a spring date, the Syndicalist, claiming popular foreign support for London, flatly declared that the congress would open there in late September. ${ }^{20}$ The ISEL was obviously manoeuvering to co-opt the congress for London. The

17 Ibid.. 9 March.

18 Ibid.. 6 April.

19 VO, 5 April, pp. 406-07.

20 Die Einigkeit, 5 April; SAN, March-April. 
ploy was successful. Although they had called for opinions on the best site for the congress, the Dutch privately preferred Amsterdam. They were now confronted with the revised British declaration, to which Cornelissen lent his support. ${ }^{21}$ The Dutch might have contested the move of the ISEL to pre-empt the congress on the basis of their survey, summarized in the Bulletin. According to its results, sympathy for the congress had been general in every country except France, where the proposal had been received "avec beaucoup de sympathie d'une part, mais avec non moins d'opposition de l'autre". Some organizations, while critical of the ISNTUC, preferred the policy of propagandizing within it. Other French syndicalists had assured the Dutch committee that Gallic opposition was due to the fact that the French unions, while of a revolutionary tendency, were "encore par trop dominés par les politiciens". Of the responses received - from Holland, the United States, Germany, Sweden, Belgium and France - fifteen had expressed a preference on the site of the congress. Britain received a single vote, that of Sweden, while Holland led the poll with six votes. But the Dutch chose not to persist in the face of the British pronouncement: "Devant ces faits accomplis, le Comité hollandais a cru devoir s'incliner et il a donc remis la besogne ultérieure de l'organisation du congrès international entre les mains des camarades de l'I.S.E.L." ${ }^{22}$ Doubtless disappointed by abandoning their hopes for an Amsterdam congress, the Dutch nevertheless sincerely wished for a successful meeting and even advanced the ISEL $£ 20$ towards organizational expenses. ${ }^{23}$

The ISEL's desire to hold the congress within its country had thus prevailed. But scarcely had the question of venue been settled when things began to go wrong. The main source of difficulties lay within the camp of the British syndicalists themselves. For it was gradually becoming a camp divided and the close working relationship of its two leading proponents, Mann and Bowman, was dissolving. Both wished to see a successful congress held, but disagreements about domestic strategy, accentuated by differences in personality, were leading to a split within British ranks. Moreover, the movement was experiencing financial troubles and economic considerations likely played a role in prompting Mann to undertake a long speaking tour in the United States, where he soon found himself embroiled in a controversy concerning the IWW's revolutionary tactics. So straitened were the circumstances of the ISEL during this period that it was unable to publish the Syndicalist for six months. Bowman, a man of rather

21 Bulletin, 6 April.

22 Ibid., 15 June.

23 Max Nettlau, Unpublished Manuscript, 1895-1914, III B, p. 605, Internationaal Instituut voor Sociale Geschiedenis, Amsterdam. 
autocratic inclinations, unsuccessfully sought in Mann's absence to assert his own predominance in the British movement, alienated many of his colleagues, and was becoming an increasingly isolated spokesman of the native syndicalist movement. ${ }^{24}$

Burdened by financial difficulties and entangled in an internecine feud, the ISEL found it difficult to fulfil its newly acquired task. Time passed and congress preparations did not proceed. Foreign supporters began to grow anxious. Cornelissen soon reminded the British of the responsibility they had assumed for the success of the congress and the need for an early distribution of its agenda. After another six weeks had passed with no word from London, Albert Jensen voiced the alarm of the Swedish Sveriges Arbetares Centralorganisation (SAC). "[L]e premier congrès syndicaliste international ne doit pas échouer", Jensen warned the British. "Un échec serait un véritable recul pour le mouvement entier." In late July Bowman finally broke the long silence by issuing a circular definitely announcing the congress -27 September to 2 October, Holborn Hall, London - and inviting participation. Though he promised a definitive agenda would soon appear, London immediately lapsed into silence again. ${ }^{25}$

\section{IV}

As the congress date drew near and its preparations followed their largely haphazard course, the debate between its advocates and the leaders of the CGT suddenly revived. Writing in La Bataille Syndicaliste, Jouhaux declared:

souhaitons que de ce congrès sortent, conformément à l'esprit qui a animé la Ligue [ISEL] jusqu'ici, des résolutions renforçant entre les travailleurs de même conception du monde entier les liens de solidarité.

La Ligue a déjà fait beaucoup, elle peut plus encore, et pour l'Angleterre et pour les autres pays, si elle ne se pose pas en adversaire des organisations déjà constituées. $\mathrm{Si}$ son congrès s'attache à favoriser l'unité ouvrière nationale dans les pays où elle n'existe pas encore.

${ }^{24} \mathrm{~W}$. Tcherkesov, the Russian anarchist exile living in London, offered a thumbnail sketch of Bowman during this period: "Bowman, half-English, half-French, quite an 'esprit boulevardier', a despotic man, wanted the entire movement for himself and kept in his hands. He quarreled with the young syndicalists, scorned them, and stood alone." From a conversation with Nettlau, ibid. The rift amongst the British syndicalists eventually led to a schism, with Bowman retaining control of an increasingly sectarian and strident rump ISEL, now devoted to dual unionism, and Mann becoming identified with the new League for Industrial Democracy. The ideological differences between the later ISEL and the League are discussed in Bob Holton, British Syndicalism 1900-1914: Myths and Realities (London, 1976), pp. 139-47.

25 Cornelissen, Jensen and Bowman in Bulletin, 15 June, 27 July and 3 August, respectively. 
Quoique pour des raisons majeures, la C.G.T. ne pourra être représentée aux assises de la Ligue, la sympathie de ses militants lui est, par avance, acquise. De l'intérieur du secrétariat international [ISNTUC], nous travaillerons dans les formes adéquates au but poursuivi, au développement des principes du syndicalisme d'action directe. ${ }^{26}$

Despite his conciliatory tone - it was now clear that the congress would be held in spite of French resistance - Jouhaux's statement in effect gave official sanction to the opposition to the congress earlier voiced by La Vie Ouvrière. The CGT would abstain from the congress. Only if it pursued goals incompatible with the very need for a syndicalist assembly as perceived by most of its advocates would the congress win French approval. Jouhaux's passing allusion to the sympathy of French militants for the impending congress, moreover, was scarcely intended to endorse the participation of CGT affiliates. Cornelissen, however, was quick to represent Jouhaux's remarks rather differently. Even if the CGT itself feared that participation would provoke and strengthen the "minorité réformiste" within it, or if it abstained "pour quelqu'autre motif", the local union associations had no need to be guided by such considerations. They were autonomous, and it would be no "défaut" for the better-known French militants to attend the congress with the mandates of such unions. ${ }^{27}$

A more direct and sustained critique of the attitude adopted by the CGT appeared from De Ambris. Though congress preparations had been somewhat deficient, the need for a meeting was urgently felt wherever syndicalists were in a minority. The USI, De Ambris reported, therefore felt compelled to support it. De Ambris defended the informational function of a congress, which would correct the situation in which the various national groups all knew something of the CGT, but very little about the circumstances of syndicalists elsewhere. Secondly, the congress could undertake the task of establishing the practical means by which these national forces could remain in permanent contact and lend assistance to one another. Effective international solidarity was important to counter the adverse action of reformist groups in the ISNTUC and to sustain anticapitalist struggles, which the reformists either tried to ignore or sought to hinder when syndicalists were so engaged. This could be achieved without

26 La Bataille Syndicaliste, 30 August. Two weeks before Jouhaux's article appeared, Solidarity, an IWW weekly published in Cleveland, Ohio, published an article entitled "What Game is Jouhaux Playing?", in which André Tridon suggested that the French government had left Jouhaux undisturbed when it had arrested other CGT officials in relation to antimilitarist demonstrations because of Jouhaux's opposition to the London congress. Tridon's article soon came to the outraged attention of VO ( 20 September, pp. 331-32).

27 Bulletin, 7 September. 
requiring the departure of the CGT from the ISNTUC, or the withdrawal of the British syndicalists from their trade unions, or the affiliation of syndicalists in other countries with the reformist central labour bodies. Syndicalism existed in different forms in different countries, De Ambris added, and the relationship between the syndicalists and the national workers' organizations in any country was determined by complex causes, which "ne pourront être discutées, encore moins critiquées, dans un Congrès". 28

De Ambris believed, finally and most importantly, that the congress should strive "de fixer la physionomie internationale du syndicalisme révolutionnaire". In nearly every country syndicalism remained a merely local phenomenon scarcely influenced by the French example. But De Ambris did not recommend a blind imitation of the Gallic model. Syndicalism was essentially action and as such was inevitably diverse; it could not be reduced to a single model, nor dogmatically fixed in a series of sacrosanct principles. The congress should not attempt to formulate a syndicalist orthodoxy. Certain of its forms, however - direct action, proletarian violence, antimilitarism, the general strike - constituted the common factors of syndicalism. By reaffirming these forms of action on the basis of an internationally shared experience, the congress could provide a valuable service. Syndicalism could then no longer be characterized by its detractors outside France as a " 'mode' exclusivement française", which, according to them, "on cherche à importer et à implanter dans les autres pays par un arbitraire esprit d'imitation". Whether the congress would be able to fulfill these and other tasks remained to be seen. But De Ambris saw two possible reasons why the congress might not succeed as well as two loci of responsibility for potential failure:

Peut-être pourra-t-on dire qu'il ne revêtira pas l'autorité suffisante ou que sa composition même, forcément hétérogène, rendra les solutions plus difficiles. Mais tandis, dans ce dernier cas, que la faute reviendra aux organisateurs du Congrès; dans le premier, c'est l'opinion de tous que la responsabilité retombera sur les camarades français, lesquels - en s'abstenant de participer au Congrès - en auront sensiblement atténué l'importance et la valeur. ${ }^{29}$

De Ambris expressed what many foreign syndicalists felt when he added that the hostility with which the French had greeted the congress proposal had created "l'impression pénible d'un lâchage injustifie". ${ }^{30}$ Nothing in French arguments appeared to justify their hostile attitude. Monatte had

28 VO, 5 September, p. 263.

29 Ibid., pp. 264-65.

${ }^{30}$ Ibid. 
earlier ${ }^{31}$ asked if the new Secretariat which the congress would create would be a Secretariat of workers' organizations, as in Berlin, or of groups of opinions, as in Brussels, where the Bureau of the Second International sat. Having declared Secretariats useless, De Ambris could not agree that the congress would necessarily found one. But if a new Secretariat were to be created, it would obviously be one linking together unions of syndicalist tendency. And in reality the ISNTUC fulfilled precisely that role for reformist unions. Non-reformist unions were merely tolerated within it, "comme des chiens dans une église", and then only because they lacked sufficient force to have any influence on its direction. De Ambris found the contention that the presence of the French in London would mean abandoning their declared goal of creating a true International through the ISNTUC devoid of force. No one had asked the CGT to quit the ISNTUC, nor that it adhere en bloc to the congress, but only that the revolutionary French unions, in accord with their rights of autonomy, participate in an individual capacity. The CGT could thereby indirectly come to know its natural allies and join in the work of coordinating their forces. What was asked was that the CGT "ne mette pas des bâtons dans les roues de l'entente syndicaliste internationale"; that it at least demonstrate some moral support for those who drew their inspiration from it. The work of establishing a true International could proceed equally well within and without the ISNTUC. French participation in the congress entailed a turning away from the self-appointed task of the CGT, and Monatte's argument had merit, De Ambris concluded in a rhetorical flourish, only if the French considered:

le Secrétariat réformiste de Berlin comme l'Eglise unique et universelle, seule dépositaire de l'absolue vérité syndicale, indiscutable, suprême et éternelle, hors de laquelle il n'est pas de salut; dans ce cas, il n'y aurait pas matière à une plus longue discussion, mais seulement à quelque étonnement légitime de notre part, à nous, hérétiques impénitents. ${ }^{32}$

De Ambris's provocative critique received a great deal of attention in Paris. Although the French response was simply signed "La Vie Ouvrière", it was in fact the result of considerable group discussion and many leading French syndicalists, including Monatte, Rosmer, Merrheim, Dumoulin, Picart, Voirin, Dumas and others, contributed to its formulation. ${ }^{33}$ They gave short shrift to the benefits De Ambris thought might come from a syndicalist congress. Its possible informational value was marginal, since

31 Ibid., 5 April, p. 407.

32 Ibid., 5 September, pp. 266-67.

33 Ibid., 20 September, p. 370. 
the syndicalist press, and especially La Vie Ouvrière, already fulfilled this function. The hope that the congress could provide the means of mutual aid between national syndicalist minorities the French dismissed as "chimérique". The delineation of the international physiognomy of syndicalism, they conceded, would prove as valuable to French syndicalists as to those of other countries. "Mais le congrès de Londres, tel qu'il a été compris et préparé, peut-il donner ce resultat? Nous en doutons." In short, while the possible advantages of the congress were minimal, the dangers it presented, particularly if it led to the establishment of a new International, were great. Noting the syndicalist-reformist split in other countries, the French declared their primary objection to be that the consequences of the creation of a new International would be the accentuation of existing schisms, the hardening of temporary divisions, and possibly the creation of splits where there were none yet. That was as "évident comme un axiome. Cela n'a pas besoin d'être démontré." 34

The French reacted sharply to the suggestion of a lâchage on their part, but they reserved their harshest criticisms not for De Ambris, but for Cornelissen. Complaining that the charge of a retreat on the part of the CGT, of an inclination towards reformism, now appeared from various quarters, La Vie Ouvrière suggested that Cornelissen's Bulletin had contributed to this "légende" by speaking of purported criticisms of the CGT from French organizations. Cornelissen himself, the French continued, believed in a "recul" of the CGT, rooted in the overriding desire to deal tactfully with reformist elements within it. The French proclaimed that though they prized workers' unity, it was an absurdity to suggest they were putting the interests of the reformists uppermost. But they did believe that divisions in national movements constituted grave impediments to any serious international movement. In the face of increasingly organized capital, would such factionalism nct ensure the failure of the workers' movement? Regarding the international movement, La Vie Ouvrière asserted, Cornelissen had "une conception personnelle qu'on peut juger étroite, périmée, ne répondant plus à l'état du mouvement ouvrier dans les divers pays". The French pointed out that the organizers of the congress had early been informed that the CGT would not participate. But they ignored this warning and persisted in their plans, hoping that in the presence of a fait accompli the CGT would be morally bound to support the endeavour. The cries of lâchage and of a CGT in retreat, La Vie Ouvrière declared, were simply the results of French refusal to yield to this pressure. ${ }^{35}$

34 Ibid., 5 September, pp. 269-70.

35 Ibid., pp. 267-68, 273. 
Cornelissen brushed aside the censure of La Vie Ouvrière. Amongst French responses to the Dutch survey there were hard words spoken, not against French syndicalism, but against certain of its leaders. Cornelissen felt obliged to report their general complaint, though he had omitted the harshest expressions of it - "n'en déplaise à Monatte ou à d'autres camarades de la Vie Ouvrière qui lisent notre Bulletin". It was not his view which was narrow and out-of-date, Cornelissen argued, but that of the French who desired to confine revolutionary propaganda everywhere to the boundaries of the large union organizations. They failed to understand the immense difficulties of conducting such propaganda within the conservative central organizations outside France. Nor did they appreciate that beneath the revolutionaries' insistence upon a congress lay "les dures expériences de la vie réelle". Cornelissen now explicitly condemned the views of La Vie Ouvrière as neither "répondant au développement actuel de notre mouvement syndicaliste international, ni comme n'étant plus même particulièrement révolutionnaire". ${ }^{36}$

In order to have the last word in the debate before the congress opened, La Vie Ouvrière delayed an issue to respond to Cornelissen's remarks. The Vie Ouvrière group insisted that in assessing the congress proposal they had been motivated not solely by the interests of French syndicalism, but by those of trade unionism "par le monde entier". Incensed that their revolutionary commitment had been impugned, the Vie Ouvrière group countered that Cornelissen himself was not a syndicalist. In an article in $\mathrm{La}$ Guerre Sociale the year before, Cornelissen had maintained that since men had interests both as producers and consumers, the trade union as an organization of producers could not, given the complexity of social life, be the sole and sufficient lever of a revolution which would expropriate the capitalists and reorganize the conditions of production and consumption. Citing the article, La Vie Ouvrière registered its own opinion that syndicalism "est précisement la conception [. . .] que l'organisation des producteurs est un levier suffisant de révolution". To the French, therefore, Cornelissen was "tout ce que l'on voudra, sauf un syndicaliste révolutionnaire". They would not permit it to be said, "pas plus par Cornelissen que par quiconque, que si les syndicats français ne vont pas à Londres, cela provient de ce qu'ils ont renié le syndicalisme révolutionnaire". ${ }^{37}$

Unknown to the French, there was at this point a possibility that no congress would be held, and Cornelissen had already rushed to England in 36 Bulletin, 21 September.

37 VO, 20 September, pp. 367-70. 
an attempt to salvage the jeopardized assembly. Its preparation had continued to be neglected in London. Moreover, labour disturbances had broken out in the capital in support of the dramatic struggle of James Larkin's Irish Transport and General Workers' Union - the nearest kin to a syndicalist union in Britain - against a massive lock-out in Dublin. Bowman now privately suggested that the agitation in London was so great that the congress should either be postponed or held in secret. Cornelissen viewed a postponement as impossible at such a late date and opposed a "clandestine congress. ${ }^{38}$ But had Bowman invoked the agitation in London in a last-minute attempt to gain time, or to avoid the congress altogether? Were it to proceed, Bowman's organizational bumbling would be plain for all to see. Moreover, events were to show that Bowman was unable to account for the money advanced by the Dutch for congress preparations. And were a congress to be held, Bowman's disagreements with many of the native syndicalists and his growing isolation within the British movement would be made evident. There were sufficient grounds why Bowman might no longer welcome the congress. Indeed, while Cornelissen was en route to London, Bowman wrote him in Paris to say that except for himself and Tom Mann there were no syndicalists in England and that the congress simply could not be held. ${ }^{39}$

Once in Britain, Cornelissen quickly grasped that the agitation prompted by the Dublin strike could prove an advantage in publicizing the work of the congress. Cornelissen's sister-in-law, who assisted in the dissemination of the Bulletin in Britain, and her husband, W. Tcherkesov, lived in London. Cornelissen could rely upon their support. $\mathrm{He}$ and Tcherkesov sought out a number of syndicalists in the capital, who "heard with indignation that Guy Bowman simply denied their existence".40 Confronting Bowman in their presence, Cornelissen bluntly told him that if he cancelled the reservation for Holborn Hall, Cornelissen would rent a hall on behalf of the Bulletin in which to hold the congress. ${ }^{41}$ Bowman did not cancel the reservation, but only the early arrival of the Dutch delegation, which supplied the required funds, secured the hall. ${ }^{42}$ Thus the

38 Christiaan Cornelissen, "Strijd, lief en leed in de Oude Socialistische Beweging en de Vakorganisaties: Persoonlijke herinneringen", p. 442, Internationaal Instituut voor Sociale Geschiedenis.

39 According to Tcherkesov. Nettlau, ibid.

40 Ibid.

${ }^{41}$ Cornelissen, "Strijd, lief en leed", pp. 442-43.

42 Der Pionier, 15 October. In the same article, Karl Roche, one of the German delegates, wrote that Cornelissen had gone to London "und machte dem Genossen Bowman Feuer unter die Sohlen. Das war", Roche added, "ein schweres Werk." 
congress which Bowman had striven so strenuously to secure for London would be held there, but ironically only because the last-minute intervention of Cornelissen and the Dutch had succeeded in forestalling his own inclination to abandon or at least postpone it.

The delegates who gathered in London carried the most diverse mandates, some having been mandated by syndicalist educational and propaganda groups, others by local unions, series of local unions, local branches of national unions, local trades councils, union federations, confederations or by national syndicalist organizations. With the exception of the CGT, all the major European syndicalist union organizations - the FVDG, the NAS, the SAC and the USI - had sent delegates. Although the Spanish Confederación Nacional del Trabajo had been banned, José Negre, one of its pioneers living in temporary exile in Paris, represented the Catalonian Regional Confederation, the most important component of the CNT. While largely efficacious, the campaign waged by the CGT against the congress had not prevented France from being represented. C. Michelet represented the Paris hatters, A. Couture six unions of building workers from Paris, and J. B. Knockaert three independent textile unions. Also from France, though scarcely as a delegate, came Alfred Rosmer to cover the congress for La Vie Ouvrière. Belgium was represented by Mathieu Demoulin, secretary of the Union des Syndicats de la Province de Liège. The Danish Fagsoppositionens Sammenslutning gave its mandate to the SAC delegate, Albert Jensen, who spoke for the Norwegian syndicalists as well, though there was no specifically syndicalist organization in Norway at the time. Despite the domestic confusion surrounding the assembly, the British delegation was the largest. Nine members represented trade-union organizations. The ISEL also sent delegates. Bowman, however, did not represent the ISEL, but elected to fill the open mandate sent by the Brazilian Regional Workers' Federation. Other Latin American workers' groups participating were the Havana Union of Café Employees, represented by $F$. Tomlinson, and two rival Argentinian organizations. The Regional Workers' Confederation had given its mandate to De Ambris, while the Regional Workers' Federation (FORA) was represented by Antonio Bernardo. ${ }^{43}$

43 The best list of delegates and organizations represented, though it is incomplete, is that * published in Die Einigkeit, 11 October. An earlier and slightly different "proof copy" of the delegates' list survives in the Jack Tanner Papers, Box 3, Syndicalism 1912-1920, Nuffield College, Oxford. The British delegation: Jack Tanner and Albert Crook, Hammersmith Engineers; A. Butcher, Bermondsey branch of the National Union of Railwaymen; E. Howell, Bristol Operative Bricklayers; A. Jones, Forest Gate Shop Assistants; Frank Lemaire, London Society of Compositors; F. Garnier, London Cooks: J. V. Wills and S. Edwards, the Bermondsey and Leicester Trades Councils, respectively. 
Thus twelve countries - Britain, Sweden, Denmark, Germany, Holland, Belgium, France, Spain, Italy, Cuba, Brazil and Argentina - had delegates at the congress. Austria adhered without personal representation. There were also links with Norway (via Jensen), and with Poland. ${ }^{44}$ Moreover, though he had no mandate from his organization, George Swasey, campaigning in England for the American IWW, also attended the sessions. ${ }^{45}$ Aside from the fact that no leading figure of the CGT was present, many of the most active and important figures in the European syndicalist movement had assembled in London as delegates. Although they had no mandates, the presence of Cornelissen and of the Russian anarcho-syndicalist Alexander Schapiro, as well as that of Tcherkesov and the fiery Swasey, added luster to the militant composition of the congress.

The question of admission to the assembly and rights within it, however, gave rise to considerable disagreement. ${ }^{46}$ The main issue in dispute con-

44 The Austrian Free Trade Unions Association had designated Jaroslaw Schebesta to represent them, but was unable to raise the funds to finance his trip from Vienna. Schebesta sent an explanation of his inability to attend along with a report on the Austrian situation to the congress, which was published in Wohlstand für Alle, 8 October. Financial difficulties may also have kept A. Wroblewski of the Polish Revolutionary Trade Union Group, which submitted an item concerning syndicalist morality to the agenda, from the congress.

${ }^{45}$ A bitterly contested struggle between centralizers and decentralizers completely dominated the IWW (cf. note 5) conference when it met from 15 to 29 September, and no decision was taken on IWW representation in London. Swasey therefore attended the London congress in an unofficial capacity.

46 An official report of the congress was never prepared and no documents, except the tentative delegates' list and the provisional agenda in the Tanner Papers, appear to have survived. Consequently, reports and/or discussions published by participants in the congress must be relied upon. Those I have been able to locate are listed here. The congress was reported by a number of its official delegates in various journals: in Argentina by Bernardo in La Protesta (29 October, $5-8$ November); in Spain by Negre in Solidaridad Obrera ( 9 and 16 October; but see also 20 November); in Italy by De Ambris in L'Internazionale (11 October); in France by Duque in Les Temps Nouveaux (18 October); in Holland by Lansink Jr and van Erkel in De Arbeid (4, 8, 11 and 15 October) and by Markmann in De Nederlandsche Zeeman (1 and 15 December); in Germany in Die Einigkeit ( 11 and 18 October) and in Der Pionier (15 October) by Roche; in Sweden in Syndikalisten (11 and 18 October, Julnummer (Christmas issue); but see also 8 November); in Denmark in Solidaritet (11 and 18 October; but see also 25 October), and in Norway in Direkte Aktion ( 11 and 25 October) by Jensen; and in Britain by Bowman in SAN (December). The congress was also reported or commented upon by other participants or observers: in Spain by Tarrida del Marmol in Tierra y Libertad (15 October); and in France by Tcherkesov in Les Temps Nouveaux (18 October), by Rosmer in VO (20 October, pp. 449-60), and by Cornelissen (C. Rupert) in La Bataille Syndicaliste ( 27 and 30 September, 1, 3 and 5 October); and by the latter in the Bultetin (12 October; but see also 19 October and 2 November). There were other reports by interested but non-participating groups; for example, the Austrian Wohlstand für Alle 
cerned the rights, if any, to be accorded to delegates representing propaganda and educational groups. ${ }^{47}$ While the Germans, supported by Michelet and others, initially argued that only delegates representing workers' economic organizations (trade unions) be admitted to the congress, the Dutch advocated the permissive line that delegates from noneconomic organizations have both voice and vote on all issues before the congress. Only after a prolonged discussion was a third course advanced by Demoulin accepted, whereby delegates of propaganda and educational groups which contributed to the diffusion of syndicalist ideas would be admitted to the assembly and allowed to take part in the debates, but without voting rights on resolutions involving material obligations on the part of economic organizations. This decision meant that Dr Pedro Vallina, representing the Syndicalist Athenaeum of Barcelona, became a "fraternal delegate" with speaking, but without full voting rights, and, more ironically, that the representatives of the ISEL, under the aegis of which the congress was being held, had become largely disenfranchised within it. ${ }^{48}$ In sum, once all mandated delegates had arrived, there were 33 ordinary delegates representing around 60 labour organizations with approximately 220,000 members, as well as 4 fraternal delegates. ${ }^{49}$

The assembled delegates were faced with an immense task. There was no clear consensus about the very purpose of the congress, and despite common recognition of the need to establish international bonds between syndicalist organizations, the momentous question of what form these

(29 October). Finally there is the British press in general, and though all the major newspapers reported the congress, their coverage is neither particularly informative nor reliable. The fullest coverage in Britain was given by the radical Daily Herald (29-30 September, 1-3 October), but even this is scanty and sometimes erroneous.

47 On the mandate issue in general, see especially Solidaridad Obrera, 16 October; but also Syndikalisten, 11 October, and La Protesta, 29 October.

48 The ISEL delegates: Evelyn Lilyan, secretary of its London branch; Gaylord Wilshire, editor of the militant Wilshire's Magazine; and Charles Roberts, a journalist. Vallina briefly recalled the congress in Mis Memorias (Caracas, 1968), p. 133. Vallina remembered the closing session as having been held at the Jewish Anarchist Club, in which Rudolf Rocker was active, but this session was more likely an informal gathering. The congress was not covered by the anarchist paper Freedom, however, though the October issue reproduced the declaration of principles endorsed there. The congress is also recalled in Jensen's "Memoarfragment" (unpaginated), Jensen Arkiv, Arbetarrörelsens Arkiv, Stockholm.

49 The figure of 220,000 is Rosmer's estimate, VO, 20 October, p. 453. Rosmer gave no indication of how he arrived at this figure, but of European organizations in 1913 the USI had around 100,000 members, the NAS around 10,000, the FVDG less than 9,000 , the SAC 3,700, the Belgian organization represented by Demoulin nearly 1,000 , the Danish Fagsoppositionens Sammenslutning 500-600. It is difficułt to say how many workers the Spanish represented, but Negre's claim to represent 60,000 (De Arbeid, 15 October) is certainly too optimistic. 
bonds should take remained to be resolved. Moreover, the attempt to formulate a declaration of principles concerning syndicalist theory and tactics would be no easy task. The congress had been postponed until the autumn to allow participating organizations time to discuss an agenda and instruct their delegates. In the general muddle of preparations, however, an agenda which has no more than a rough compilation of suggestions submitted by various interested groups was hastily assembled only shortly before the congress. The hopes for serious advance discussion of its contents had come to nought. The agenda ranged across a broad number of topics covering theory and tactics, antimilitarism, international scabbing, emigration, international organization, an international newspaper, an international language, and, finally, the religion and morals of the proletariat. It was unlikely from the start that the entire agenda could be dealt with during the congress.

\section{VI}

In London, where the First International had been founded nearly fifty years before, syndicalists of Europe and Latin America who considered themselves its true heirs opened the First International Syndicalist Congress on September $27 \mathrm{th}$. But from the beginning conflicts began to emerge which would recur throughout the congress. The mandate issue elicited disagreements, as mentioned, and the selection of officers gave rise to the first of the personal clashes which would plague the sessions. Bowman played a leading role in these personality conflicts. Domestic quarrels had put him at odds with many of the British delegates, and his relations with Cornelissen had been strained to the utmost by the latter's last-minute intervention to salvage the congress. The German and Dutch delegations, ${ }^{50}$ thoroughly unhappy with Bowman's mismanagement of preparations, naturally sided with Cornelissen. Bowman's position was rendered further delicate by unresolved questions concerning congress finances. ${ }^{51} \mathrm{He}$ was not, however, without allies. From the beginning he

50 The German delegation, all of the FVDG: Karl Roche, Karl Windhoff and its executive officer, Fritz Kater. The Dutch delegation, all of the NAS: Thomas Markmann, Seamen's Union; Bernard Lansink Sr, textile workers; Bernard Lansink Jr and van Erkel, building-trades workers; C. J. Wesseling, municipal workers; and A. van der Hagen and A. van den Berg, cigar-makers and tobacco workers.

51 The financial question revolved around who was responsible for re-imbursing the Dutch the $£ 20$ advanced to Bowman for the preparation of the congress. A committee assigned to review the matter reported in closed session that Bowman had submitted no receipts for expenses and that no conclusion could be reached concerning the disposition of the deficit. No decision was made in this tumultuous session, though the British delegation entered a vigorous protest against Bowman. On the final day of the congress, 
allied himself with the French delegates and he made an assiduous effort to woo De Ambris. ${ }^{52}$ Another member of the Italian delegation, Silvio Corio, lived in London and was on good terms with Bowman. Thus the French and Italian delegations tended to support Bowman as did the Spanish, though more infrequently. ${ }^{53}$ These groupings were not definitive, however, and did not rest solely on personal issues, but appeared to be reinforced by a difference in temperament, again not clear-cut, between the syndicalists of Southern and Northern Europe. ${ }^{54}$

the representatives of the London branch of the ISEL, aware of the claims for reimbursement lodged by the Dutch, disclaimed all responsibility for its organization. Bernardo observed in La Protesta, 6 November, that the closed session had made evident "the very bad conduct of Bowman". Die Einigkeit, 18 October, was marginally more charitable: "But it is here expressly emphasized that material dishonesty may not be credited to Bowman. In financial matters people like Bowman are harmlessly cut off from the world. They spend money so long as there is some, and when it is gone they trust in providence and let the creditors do as they please." Bowman himself later complained that the organizers had been short of funds and observed that "had the I.S.E.L. stopped because of money considerations the Congress could not have been held at all". SAN, December. But he neglected to add that he himself had proposed its cancellation, or at least its postponement; nor did he mention the $£ 20$ advance from the Dutch.

52 Rosmer to Monatte, mercredi matin (1 October), Monatte Archives, Institut français d'Histoire sociale, Paris.

53 The Italian delegation: De Ambris, USI; Corio, Parma Trades Council; and Edmondo Rossoni, Bologna Trades Council and the Syndicalist Union of Milan. The Spanish delegation, in addition to Negre, included J. Suarez Duque, mandated by thirteen unions of various type of Coruna, and José Rodriguez Romero, who represented three unions of agricultural workers and bootmakers of Alayor and Mahon as well as an Alayor women's union. Romero delivered a well-received discourse acclaiming the equal rights of women at the congress. A fourth French delegate, Louis Perrin, representing the Vichy Bourse du Travail, arrived late for the congress. He attended its sessions only irregularly and was not issued a congress card.

54 Among other things, Bowman accused Cornelissen of distorting translations and of trying to manipulate the congress. The Dutch and German delegations on the one hand and the Italians and some of the French on the other proved temperamentally indisposed towards one another. Disparate conditions of economic development and labour organization amongst the countries represented may have played a role. Although it was the largest organization represented, the Dutch and the Germans apparently did not take the USI represented by De Ambris, for example, very seriously; they treated it, according to Rosmer, letter to Monatte, jeudi soir (2 October), Monatte Archives, as a "quantité négligeable". The Daily Herald, 1 October, also noted the Bowman-Cornelissen split which corresponded broadly to national differences, and attributed the slow progress of the congress to the "strong individualism of the delegates". Rossoni, as "coquet comme plusieurs femmes", was given to castigating the Germans and the Dutch. They in turn took him for a fool, and Rosmer opined that they were not far wrong. De Ambris developed a "véritable haine" for Kater, Rosmer to Monatte, 1 October. Rossoni, Michelet and other Latin delegates habitually interrupted the proceedings. At one point an exasperated Windhoff exclaimed: "Les Français, les Espagnols et les Italiens parlent tout le temps [.. . . Les Allemands et les Hollandais sont les seuls qui discutent convena- 
In a three-way contest between Bowman, Jack Wills and Kater, the latter two were elected to the joint presidency of the congress. The assembly also selected Bowman and Cornelissen to act as congress secretaries and to discharge the immense task of providing a running translation of the proceedings. Although he commanded three languages, Bowman did not take his office very seriously and was quickly supplanted as translator by Schapiro. ${ }^{55}$ Kater opened the second day of the congress with a presidential address stressing its importance in view of the rapid development of industrial capitalism and commending the general progress of the syndicalist movement. Doubtless mindful of the lengthy and cumbersome agenda, he emphasized that the first syndicalist congress should concentrate upon two principal points: first, to formulate a declaration of principles concerned not merely with immediate benefits, but which attacked capitalism in its essence and unequivocably demanded its ultimate abolition, so that workers would realize clearly the objective of syndicalism; second, to establish an international connection among syndicalist groups in order to provide firm support of the impetus towards the genuine emancipation of the proletariat. "Si donc nous n'arrivons qu'à formuler une déclaration de principes pour le mouvement syndicaliste et à jeter les bases d'une entente internationale, nous pourrons être contents déjà avec cette double oeuvre." 56

If Kater had hoped the assembly would turn quickly to these weighty tasks, he was to be disappointed, for the congress next moved into closed session to discuss a protest lodged against the presidency of Wills. Michelet proceeded to point out that at the time of the election many delegates had been unaware that Wills was a local councillor in one of the boroughs of London. A number of them, including the French and Spanish delegations, Demoulin and Bernardo, had formulated a protest against

blement", VO, 20 October, p. 451. The provocation was not wholly one-sided. The Daily Herald, ibid., observed that Karl Roche perambulated the congress floor and interjected comments which had the result of "often raising the ire of his French comrades". The Spanish delegation, for the most part, avoided being drawn into the personal disputes, and sought at times to soothe their colleagues and call attention back to the more serious work of the congress. And no one "ne fut plus surpris ni attristé par cet antagonisme que Cornelissen", VO, ibid. Though these divisions were clearly felt in the congress, they can be unduly emphasized, and Rosmer's claim (ibid., pp. 450-51) that from the beginning two inalterable groups came into being which formed opposing blocs on all issues of the congress is a gross exaggeration. Divisions within the congress are also discussed in Nettlau, ibid.

55 Schapiro was not only a veteran of the 1907 Amsterdam International Anarchist Congress, like Cornelissen, but was also a member of the International Bureau which the congress had appointed.

56 La Bataille Syndicaliste, 1 October. 
Wills's election. On behalf of these delegates Michelet declared it impossible that a politician preside over a syndicalist congress. "Nous sommes des révolutionnaires [...]. Nous ne voulons pas de la tutelle des politiciens." In the extremely animated discussion which followed, Roche supported Michelet's protest on behalf of the Germans: "Comme syndicalistes [. . . ] nous sommes antiparlementaires. On se moquerait de nous, en Allemagne, si nous acceptions Wills comme président. Les Anglais doivent comprendre notre position." Wills, a particularly active militant in the London building trades, sought to vindicate himself. Describing himself as a committed syndicalist, he argued that the position of borough councillor in London did not have a political character, had nothing to do with the formulation of laws, and was not equivalent to a municipal councillor in Paris, as Michelet seemed to believe. A councillor's duties were strictly administrative and borough government, he contended, was entirely independent of the politics of the British state. "Like everyone here, I am antiparliamentary", he continued.

But I am not surprised that a protest against my election is raised today. Bowman has provoked it. For there is a serious dispute between the English comrades and Bowman. And before you leave London I want you to know that I have the confidence of my comrades whereas Bowman no longer has it, and that if the congress does not have all the success that it ought to have, he is responsible for $i t$.

Against Wills it was argued that even a mere administrator was a member of the state by virtue of his putting its directives into effect. While stressing that Wills deserved every consideration of the assembly, Michelet insisted that as a matter of principle the protest of the objecting delegates be upheld. But when to facilitate the work of the congress Wills orally tendered his resignation, the Dutch repudiated it. The congress, they maintained, could not accept it. Wills had been elected as a representative of a syndicalist workers' organization: It was of little import if he was also a borough councillor. The Dutch remarked that they could not be as exclusivist as the French and the Spanish in such cases. "Nous ne demandons qu'une chose, c'est qu'il marche avec nous sur le terrain économique. Il y a, dans nos syndicats, des chrétiens, des social-démocrates. Faudra-t-il les expulser?"57

The dispute highlighted a constant and unresolved tension in syndicalist ideology. The non-politicism of syndicalism could be understood in different ways. On the one hand, political action was abjured not only as a

${ }^{57}$ The fullest accounts of the presidency dispute are to be found in Solidaridad Obrera, 16 October; Syndikalisten, 18 October; and VO, 20 October, pp. 453-55. The quotes are from VO. 
waste of energy but as a positive hindrance to working-class progress. Thus, while Wills proclaimed his antiparliamentarism and tried to minimize the political significance of his position as councillor, Michelet and his supporters saw in his presidency a violation of the principle of the political neutrality of syndicalism. The Dutch, on the other hand, considered their own objections to be based upon this principle. Syndicalism sought to organize all class-conscious workers, irrespective of their political or other beliefs. Workers were free to pursue whatever action they wished, includ-ing political action, outside their union as long as they did not seek to import their political convictions or concerns in to the labour organization itself, where attention was to be focussed solely upon the economic struggle. This is what the Dutch had in mind when they argued that to remove Wills from the presidency would be a departure from the syndicalist principle of political neutrality. ${ }^{58}$

The Dutch felt strongly enough about the issue that when Wills's resignation was accepted by a substantial majority, Markmann stunned the remaining delegates by declaring: "La question se pose pour nous [...] de savoir si le Congrès doit continuer ou si nous devons retourner chez nous. Nous ne pouvons pas admettre que tous les délégués n'aient pas les mêmes droits et qu'on puisse en écarter un de la présidence."59 Feathers were unruffled, however, and an accord reached: the British would nominate one amongst them to take Wills's place and the Dutch would remain in London. Jack Tanner was later unanimously elected to join Kater as co-president. With the presidency dispute behind them, the delegates still did not turn immediately to the tasks emphasized by Kater as of prime importance. Resolutions protesting the repressive treatment of syndicalists in Portugal and the British governmen's use of armed coercion against the Dublin strikers were discussed and passed. Organizational questions consumed more time. Though welcomed as fulfilling an important informational function, the national reports sprinkled throughout the proceedings were even more time-consuming. ${ }^{60}$

The submission of two reports from France demonstrated the lack of cohesion within the French delegation. The absence of the CGT meant

58 Although in France the Charte d'Amiens guaranteed individual members of the CGT complete liberty to engage in political action, union officials were discouraged from doing so. Nonetheless, the incongruous situation arose wherein members of the CGT's Confederal Committee actually sat as socialists in the Chamber of Deputies. Only in 1911 were the CGT statutesaltered to prevent the candidature of officials.

59 VO, 20 October, p. 455. The Dutch were not alone in threatening to leave the congress. On several occasions, especially when personal disputes came to the fore, various small groups of delegates threatened to withdraw.

60 The fullest account of the reports is that given in De Arbeid, 4, 8 and 11 October. 
that no official report was presented from that organization. But Michelet and Couture, both members of the CGT, submitted a written report which manifested an obvious sensitivity to some of the issues raised in the precongress debate. The report noted that the French "revolutionary organisation was imagined to be at a standstill, but it was not going backwards. It preserved its purely revolutionary aspect and refused to accept the interference of Parliamentarians." French syndicalism remained "a driving force against militarism, patriotism, the State, and capitalism, and anything which prevented the march of the movement". ${ }^{61}$ Knockaert, who represented textile unions of Lille, Tourcoing and Roubaix not affiliated with the CGT, took the rostrum to present a contrary view. He upbraided the CGT and the deference it showed the reformists. The unions he represented, Knockaert declared, were not in the CGT because it harboured the local reformist organizations, some of which worked with a local blackleg association. Moreover, they were excluded from the CGT because they could not share its opinions. They advocated fully autonomous organizations which could proselytize for syndicalism among the workers. This was not possible in the CGT. The unions for which Knockaert spoke further evidenced their opposition to the CGT by urging the London congress to work for the creation of an independent Syndicalist International. ${ }^{62}$ Michelet and Couture could not share this recommendation.

Only on the fourth day did the congress take up the question of "Theory and Tactics". A resolution committee, beginning with a written draft submitted by the Dutch delegation, had spent the preceding evening in formulating a declaration of syndicalist principles. The committee's resolution elicited a lengthy and lively debate in which every delegate actively participated. Much of the discussion concerned whether and how syndicalists ought to influence the state. Corio wished to eliminate a section asserting "the proletariat can only effectively influence the state by methods of direct action", on the grounds that it might lead the workers to begin to expect things from the state. The state should be ignored, Corio insisted, and attention directed toward securing their demands directly from capitalism. Others opposed Corio's proposed change as untenable.

61 Manchester Guardian, I October.

62 De Arbeid, 11 October. Rosmer, who certainly did not share Knockaert's views, granted that he had been "magnifique" in his speech and noted that the Germans were delighted with it. "Knockaert est leur homme." Letter to Monatte, 2 October. According to Les Temps Nouveaux, 18 October, the organization in-Lille represented by Knockaert had been expelled for its revolutionary tendency from the national textile federation, a markedly reformist body within the CGT. 
Just as one lived under the economic tyranny of capitalism, one lived under the political tyranny of the sfate; neither could be ignored. Wills observed that there was some confusion among the delegates between political and parliamentary action. While parliamentary action was to be opposed, direct action could profitably influence the state. If this were not so, what would be the sense of antimilitarist agitation for example? Karl Roche and others contended that although the struggle was an economic one, the possibility of directly pressuring the state ought not be eschewed if it could "secure social legislation benefiting the workers. ${ }^{63}$ The question of workers employed by various branches of the state also came up.

De Ambris raised another point involving the state. Whereas the declaration asserted that the congress recognized that workers everywhere suffered from "political and economic" slavery or suppression, De Ambris argued that they suffered from capitalist slavery or exploitation, and proposed that the phrase "capitalist system" be employed in lieu of "political and economic" throughout the document. Cornelissen responded that the phrase "political and economic" already and of itself described the oppression of the capitalist system. ${ }^{64}$ The discussion on this point was prolonged and De Ambris, arguing fervently and persistently, secured support from the remainder of his delegation, from the French and others. Although the evolving debate was far from unclouded, it was becoming clear to some delegates that the proposals involved considerably more than a linguistic clarification, for they would have the collective effect of removing all direct references to the essentially antistatist syndicalist attitude from the statement of principles. Thus C. J. Wesseling declared that the National Federation of Municipal Workers of Holland could not join the new International if the proposed changes were accepted. Bernardo noted with obvious disapproval that at this stage "Theory and Tactics' was taking a socialist character", by which he meant a non-revolutionary character. ${ }^{65}$ In the ensuing discussion the opponents of the changes sought to demonstrate what was really at issue, particularly concerning the changes De Ambris had been insisting upon. Though not a delegate, Tcherkesov was particularly active. Speaking privately with the French delegation, he pointed out that De Ambris's alteration would avoid any explicit reference in the declaration to the syndicalist attitude to the state. The French thereafter ceased to support De Ambris's proposal. Tcherkesov also spoke to Corio, himself an anarchist of long standing, and

65 Wesseling, ibid; Bernardo in La Protesta, 5 November. 
sternly repeated this elucidation. ${ }^{66}$ With others at work persuading remaining resisting delegates, De Ambris's support rapidly ebbed. Jensen summed up the situation:

Through the exclusion of the phrase "political and economic" the congress had only spoken out against economic slavery but not against the state. Because of this, one had, in actual fact, placed oneself against one's will on a social-democratic level. It might well be possible to become free of the economic repression of capitalism through the establishment of a socialdemocratic state. That was not what was wanted. ${ }^{67}$

Instructed to revise the declaration on the basis of the preceding discussion, the resolution committee submitted the following draft:

That this Congress, recognising that the working class of every country suffers from capitalist slavery and State oppression, declares for the class struggle and international solidarity, and for the organisation of the workers into autonomous industrial Unions on a basis of free association.

Strives for the immediate uplifting of the material and intellectual interests of the working class, and for the overthrow of the capitalist system and the State.

Declares that the class struggle is a necessary result of private property in the means of production and distribution, and therefore declares for the socialisation of such property by constructing and developing our Trade Unions in such a way as to fit them for the administration of these means in the interest of the entire community.

Recognises that, internationally, Trade Unions will only succeed when they cease to be divided by political and religious differences; declares that their fight is an economic fight, meaning thereby that they do not intend to reach their aim by trusting their cause to governing bodies or their members, but by using Direct Action, by the workers themselves relying on the strength of their economic organisations.

And in consequence of these recognitions and declarations, the Congress appeals to the workers in all countries to organise in autonomous industrial Unions, and to unite themselves on the basis of international solidarity, in order finally to obtain their emancipation from capitalism and the State. ${ }^{68}$

${ }_{66}^{6}$ On Tcherkesov's role, Nettlau, op. cit., pp. 605-06.

${ }^{67}$ Syndikalisten, 18 October.

68 SAN, December. Rosmer noted that the declaration was the work of a French delegate, VO, 20 October, p. 456. But while Couture, a member of the resolution committee, may have put the finishing touches to the document, it does not deviate greatly from the original draft submitted by the Dutch and reproduced in De Arbeid, 3 September. Tanner opened the final day of congress by emphasizing that the declaration specifically precluded political action of any kind, contrary to a misconception in the London press, Morning Advertiser, 3 October. His correction was obviously elicited by the Daily Chronicle's confused article of 2 October, which claimed that the declaration "was worthy of note because it admitted the trade union view of the importance of political action" (which prompted Jensen to quip: "Political-parliamentary syndicalism! That is the latest sensational news!" Syndikalisten, 18 October). 
The revised declaration had, in effect, accentuated the antistatist position of the syndicalists rather than moderating it, and thereby repudiated the changes for which De Ambris had so assiduously struggled. He signalled his defeat by making its acceptance unanimous.

\section{VII}

The assembly next turned its attention to the major issue of international organization and the normalization of relations between syndicalist - associations. The question which had figured so prominently in the discussions and debates preceding the meeting had finally come before the congress. Everyone was in accord that some kind of permanent linkage ought to be created; there was less unanimity concerning its form. While the agenda bore a recommendation from the German FVDG and the Swedish SAC that a Syndicalist International be created, other agenda submissions were less demanding. That of the USI for example, called only for the "definition of a permanent relationship" between the various syndicalist organizations. ${ }^{69}$

The resolution committee had been working with two proposals on the question of international organization, submitted by the German and Italian delegations. The former called for the establishment of an international Syndicalist Secretariat to have its seat in Amsterdam and its administration in the hands of the Dutch. It also called for a relatively high dues schedule to assure the efficiency of the new International, and specified that the dues be independent of the subscription fees to the bulletin which it would publish. The Italian proposal sought the creation not of an International, but only of a committee of relations which would serve to maintain contact between syndicalist organizations, and which would derive its revenue from the subscription to the bulletin alone, which would be kept low. The committee left open the question of the form of body to be created, but proposed that its seat be in Amsterdam under the guidance of the Dutch. Much of the debate turned around the question of the possibility of schisms occurring within the labour movement as a result of the particular form given an international syndicalist organization. In many of the countries represented - in Germany, Holland and Sweden, for example, and in Italy as well - there had already been a split between the syndicalist and reformist labour organizations. The affiliation of the national syndicalist bodies of these countries with a new and autonomous International was not problematical as it was in countries such as Britain, where the split had not taken place, or in France, where the situation was

69 "Provisional Agenda", Tanner Papers. 
ambiguous and complicated by the adherence of the CGT to the ISNTUC. The case of France became central to the debate. ${ }^{70}$

The proponents of a formal International at first dominated the discussion. Knockaert delivered an eloquent appeal for its creation, while the German and Dutch delegations sternly insisted upon the necessity of a revolutionary International standing sharply opposed to that in Berlin. Others were less convinced, however, and a few were uncertain that their mandates sanctioned the actual formation of an International. Like Demoulin, Duque insisted on the importance of the new International being radically unlike that of Berlin, but nonetheless favoured the creation of a correspondence committee for the present, suggesting that the question of a formal International be postponed to the next congress. De Ambris vigorously opposed the German proposition. He considered it absurd to want to create a separate International alongside the ISNTUC, particularly in view of the small number of organizations represented in London. Declaring that the French would not adhere and that countries such as Britain where the syndicalists worked within the old organizations could provide no support, De Ambris calculated that a separate syndicalist International would not include at the beginning over 500,000 members. The figure would be insignificant in comparison to the millions represented in the ISNTUC.

Though De Ambris's opposition to the creation of a formal Secretariat came as no surprise, the arguments he employed against it astonished some of his fellow delegates, particularly in view of the scepticism he had expressed in the pre-congress debate concerning the ISNTUC, and the fact that De Ambris himself had been one of the most active promotors of the split in the Italian Confederazione del Lavoro, which had led to the formation of the USI the year before. Nonetheless, in arguments remarkably reminiscent of those of La Vie Ouvrière, De Ambris maintained that the creation of a rival International would only cause splits within the working class, especially in France, and this was best avoided. Citing the case of the hat-makers of France, he pointed out that they were federated, confederated, members of the CGT and of the international federation in their industry. Hence they could not join a new International without breaking their ties with the CGT and their international federation. But since the hat-makers remained autonomous in terms of propaganda activity, there was nothing to prevent them from supporting an international syndicalist committee of information by subscribing to its bulletin. For his part, De

70 The best sources on the discussion of the question of international organization are those found in De Arbeid, 15 October; Les Temps Nouveaux (Duque), 18 October; Syndikalisten, 18 October; and La Protesta, 7 November. 
Ambris asserted, the London congress had and could only have a single goal: that of creating permanent contact among the syndicalist organizations which could not be represented in the ISNTUC. This required only the establishment of a bureau of information and a bulletin, which would permit the French to adhere as well. Anything further was unnecessarily divisive and a transgression if it meant creating an organization which might be harmful to the work of the CGT in the ISNTUC, and might encourage schisms in countries where there were none yet. The French delegates, except Knockaert, supported De Ambris by arguing that the creation of an International in opposition to the ISNTUC would create dangers for working-class unity and specifically for the CGT. Michelet and Couture argued that an accord could be reached between reformists and revolutionaries once the latter were sufficiently numerous to carry the former along with them. ${ }^{71}$

But De Ambris's solicitude for the ISNTUC failed to strike a responsive chord in such delegates as Bernardo and Jensen. The Germans and the Dutch also found little merit in De Ambris's position. Roche asserted that De Ambris opposed all organization, and pointed to the millions of organized workers who did not belong to the ISNTUC. Had the congress been better organized, there would have been delegates present from as far away as Japan. "Nous sommes venus ici pour fonder une Internationale. Si les Français et les Italiens ne veulent pas venir avec nous, eh bien, nous fonderons une Internationale entre Allemands et Hollandais."72 De Ambris sarcastically responded that he too wanted to found an International, but with neither the Germans nor the Dutch. The elder Lansink remarked that Holland was loath to be responsible for causing schisms amongst the proletariat, but schisms had long occurred, and within centralist organizations as well. The Dutch sought to create a Syndicalist International only because they believed it would ultimately serve to overcome differences and thereby contribute to the unity of the proletariat; not only would all workers eventually come to it, but all would attain equal fulfilment within it.

71 La Bataille Syndicaliste, 5 October; La Protesta, 7 November. Duque thought very little of this expectation of Michelet and Couture: "C"est le même argument que nous présentent les social-démocrates quand ils parlent de s'approprier l'Etat, sans jamais compter que, malgré leur majorité, ils seraient forcés de faire la révolution." Les Temps Nouveaux, 18 October. The case of Couture illustrates the effect the crisis in the CGT had upon the international views of some of its radicals. In May 1909 in Travailleur du Bâtiment Couture proposed, in opposition to CGT's policy, the creation of an independent International for revolutionary unions. In 1913 he argued against the creation of such an International because it would jeopardize the unity of the French organization. 72 VO, 20 October, p. 449. 
The Italian proposal, however, did not lack support in addition to that provided by the majority of the French delegation. The Spanish, who until the final debate had avoided taking sides on the issue, declared in favour of a committee of information and endorsed Duque's suggestion that the question of a Secretariat be postponed to the next congress, the organization of which the resolution put in the hands of the committee to be established. In order to remove doubts, however, Negre asserted that as soon as the International became a fact the tens of thousands of workers he represented would immediately adhere. Bernardo endorsed the Spanish view. Like Negre, he stressed that the body he represented, the FORA, would adhere to a new International as long as it was distinctly revolutionary, as would other labour elements in South America. De Ambris's claim that a new International could expect at best a half-million members was wide of the mark, Bernardo optimistically asserted, since from South American countries alone 600,000 workers were likely to adhere. ${ }^{73}$

Although authorized by the SAC to support the creation of an International, Jensen adopted a rather different approach. Noting that the Germans and the Dutch were astonished that the French and Italians did not understand their position, Jensen observed that it could equally be said that the Germans and the Dutch did not attempt to understand the position of the workers' organizations of other countries. A possible schism in France would have grave consequences. Jensen did not believe the work of the CGT within the ISNTUC to be significant, but viewed the reaction as particularly severe in recent years in France and questioned the wisdom of risking a schism within the CGT, which would lessen the workers' power of resistance against the government and the employers at a critical time. He therefore proposed that the congress only appoint a committee to administer Cornelissen's Bulletin and that it defer the question of a more substantial organization to the next congress. With the prospects of securing a majority for their proposal receding, but with assurances that the creation of a formal International would receive wide support at the next congress, the German and Dutch delegations ultimately relented and rallied to the Italian proposal. It would be unfortunate if schisms occurred in France, Kater observed in recalling the German proposal, but it was unavoidable. "The revolutionaries must sooner or later come over to us."74

Though a major step toward mutual accord, the withdrawal of the German proposal did not assure equability in the remainder of the 
deliberations. No unanimity could be reached on the question of the seat of the committee, or Information Bureau as it would be called. The Germans and the Dutch staunchly supported the proposal drafted in committee which called for the Bureau to be located in Amsterdam and its administration entrusted to the Dutch, while De Ambris argued mightily and ceaselessly against it. He objected strongly to situating the Bureau in a country as small and little known as Holland. London would not do, for the British syndicalists were themselves obviously divided. The solution, De "Ambris maintained, was to assign the Bureau to the Fédération de la Chapellerie in Paris. ${ }^{75} \mathrm{He}$ called upon all his resources to defend his proposition. Though he cast his arguments in other terms, few delegates failed to realize that De Ambris's real objection concerned leaving the Bureau in the hands of the Dutch. The Dutch, with German support, would be free to work through the Bureau for the creation of a genuine International. Like De Ambris, the majority of the French delegation opposed the establishment of a rival International. To secure the Bureau for Paris would mean putting it into more moderate hands and might also placate the CGT (to which Michelet's Fédération belonged), which had clearly demonstrated its hostility to the idea of a Syndicalist International. For De Ambris, Dutch-German preeminence within the Bureau had to be avoided at all costs.

Most delegates, however, agreed with Bernardo that the reasons why the Bureau could sit in neither Paris (the CGT) nor Berlin (the ISNTUC) were self-evident, and that it therefore should be entrusted to the Dutch. As a last resort, De Ambris now proposed that the voting procedures be altered. To vote by delegate, as had been done thus far, obviously favoured those countries with the largest delegations and the results were not necessarily commensurate with the number of workers represented. He proposed instead that the vote on this issue be taken by nationality. ${ }^{76}$ Lively protests were lodged against the proposal. Kater opposed it vigorously, as did Rodriguez Romero, who branded it unacceptable as "contraire au principe fédéraliste", ${ }^{77}$ and therefore non-syndicalist. A vote (taken by delegate) determined that the initial voting procedures be continued. His proposal

75 De Ambris had originally intended to propose London as the seat of the Bureau until his experience in the congress revealed to him the deep divisions amongst the British syndicalists. But his proposal to entrust the Bureau to Michelet's Fédération in Paris amazed Rosmer. Letter to Monatte, 2 October.

76 SAN, December. Bowman defended De Ambris's proposal here, but falsely added that the majority of delegates preferred Paris.

77 VO, 20 October, p. 457. 
defeated, an infuriated De Ambris announced his withdrawal from the congress. ${ }^{78}$

Following further discussion, the delegates voted to create an International Syndicalist Information Bureau which would act as a correspondence centre, foster international solidarity, and organize congresses. Each affiliated country would appoint a correspondent attached to the bulletin which the Bureau would publish and from which it would draw its revenue. The Bureau would sit in Amsterdam under the direction of a committee to be appointed by the Dutch syndicalists. The ten sections of the resolution were accepted unanimously, except that which assigned the Bureau to Amsterdam, which secured nineteen votes against ten for Paris. ${ }^{79}$ This completed the basic work of the congress. Lack of time prevented the discussion of the question of antimilitarism in the final sessions as had been hoped. In lieu of this, Kater stressed in his closing remarks that syndicalists were mortal enemies of all militarism, and when sufficiently organized in every country they would make war impossible. ${ }^{80}$ Kater observed that since the congress had been able to deal with only a few points on the agenda, the remaining items would be transferred to the next congress, to be held in Amsterdam.

The manifestations of the congress were not yet complete, however, for in the evening there was a large and enthusiastic public rally at Holborn Hall intended to crown and celebrate the congress. With the exception of Italy, all the countries with delegates at the congress were represented. The declaration of principles was read out and fervently applauded. The firebrand leader of the Dublin strikers, James Larkin, had accepted an invitation to speak if circumstances permitted, but was unable to get away from Dublin. But there was no lack of spirited speakers who almost seemed to be vying in rebelliousness before the responsive crowd. Bowman was followed to the rostrum by two socialists, Ben Tillett and the Greek M. Drakoulis, but the remaining addresses, in the words of one reporter, "were all pure Syndicalism in various languages". 81 The speakers included Swasey of the USA, Roche of Germany, Lansink Sr and Markmann of

78 De Ambris had been unhappy with the voting procedures from the beginning. Later in the day Rosmer encountered De Ambris, who following his withdrawal from the congress had had a dinner "avec un fiasque pour lui tout seul. Il est tres gai. [. . . Mais il est enragé contre Cornelissen et contre Kater! Il souhaite leur mort pour la paix du monde et le progrès du syndicalisme." Letter to Monatte, 2 October.

79 The resolution is reproduced in full in Die Einigkeit, 11 October.

80 Der Pionier, 15 October.

81 Manchester Guardian, 3 October; see also the Morning Post, the Daily Chronicle and the Daily Herald, all 3 October. LKA Protesta, 8 November, presents the glowing but not untypical response of a congress delegate (Bernardo). 
Holland, Romero and Negre of Spain, Tanner and John Turner of Britain, and Michelet of France. Observers and participants alike were stirred by the rally, and the jubilant and spirited climate of international cordiality and solidarity helped to give the troubled congress a friendly conclusion.

\section{VIII}

In the wake of the congress the assessments began appearing. Those predisposed to welcome its failure felt fully justified in pronouncing that result and in emphasizing the often disorderly character of the proceedings in support of it. ${ }^{82}$ The exponents of social democracy directed none but the most critical words toward the congress. In Britain, Justice, nominally the organ of the British Socialist Party, pointed to the admission of German and Dutch delegates that their tactics included attempts to capture members from social-democratic unions as indicating the "divisionist" character of the congress. The declaration of principles was "a strange mixture of Socialism and Anarchism [...]. In fact, the influence of Anarchism was apparent throughout, though it has taken unto itself the name of Syndicalism." 83 The judgment of the German social democrats was even more severe. The organ of the Freie Gewerkschaften declared the congress to have been "unquestionably a complete fiasco". In its view no significant unions were represented. The declaration of principles "contains nothing but trite phrases", and the Information Bureau, the Germans predicted, would not be able to collect even the purposefully low subscription fees of its potential members. ${ }^{84}$

A judgment nearly as harsh appeared from De Ambris. In an angry critique he declared the disappointing congress to have "manqué son but pour une bonne part". The resolution dealing with the composition and seat of the committee "mérite notre plus vive protestation". To imprison the committee in "un petit pays quasi ignoré comme la Hollande, c'est le condamner à la stérilité, surtout lorsqu'on pense à la mesquinerie de pensée dont ont fait preuve au Congrès les représentants des organisation[s] hollandaises". De Ambris railed against the voting system which had produced this lamentable consequence. The London assembly could

${ }^{82}$ Thus the conservative Morning Post, 3 October, asserted that because of the differences and disruptions of the proceedings "little light has been thrown on the ideas for which the Syndicalists stand". The somewhat more perceptive New Statesman, 4 October, noted that the position of the congress "with regard to Parliamentarism, the organization of Trade Unions and the value of direct action was quite clearly and definitely expressed".

83 Justice, 11 October.

${ }^{84}$ Correspondenzblatt der Generalkommission der Gewerkschaften Deutschlands, 25 October, p. 658. 
no longer be considered a real congress; rather, it must be regarded as "la réunion préliminaire de ce que sera demain le vrai Congrès syndicaliste international". If this goal could not be realized for several years, patience would be required. "L'important en cette matière n'est pas tant de faire vite que de faire bien." 85

Another group obviously predisposed to acclaim the failure of the congress were those French syndicalists who had challenged its right to existence from the beginning. Rosmer considered the assignment of reporting it a "sinistre corvée"; when its sessions were terminated, his first thought was simple and direct: "Bon débarras!"86 The unswervingly critical account he published in La Vie Ouvrière stressed the personal conflicts of the assembly, which he buttressed by reproducing the harshest parts of De Ambris's article. The "opérations maladroites" of the congress as a whole, Rosmer declared, could only be "dommageables au syndicalisme international, et même au syndicalisme tout court". The results of the congress did not impress him. The declaration of principles was not "d'une clarté éblouissante". He predicted that only the German, Dutch and Swedish syndicalists would adhere to the Information Bureau; the Italians were unlikely to join and neither the Spanish nor its French advocates were in any position to provide it much support. The congress failed, Rosmer asserted, for two main reasons. The first was attributable to its very poor preparation. A second and more important reason was that the delegates themselves were divided on fundamental issues. Chief among these was the possibility of creating further schisms within the labouring classes. "Pour les Allemands et aussi pour les Hollandais, la division des forces ouvrières doit devenir la règle. Parce qu'elle existe chez eux, ils la veulent partout." Rosmer reiterated the arguments the French had employed before the congress. Though the struggle in countries where social democracy dominated the labour movement was difficult, it was nevertheless necessary to deal with the existing unions there, despite the moderation of their leadership, and win them over to syndicalist ideas. Rosmer professed to see changes in Britain, America and even Germany as demonstrating the correctness of this policy. Hence the French desire to remain in the International Federation of Trade Unions and to preserve the contacts of the CGT with the unions of these countries. "Ce n'est pas l'heure de désespérer ni de changer de méthode." 87

${ }^{85}$ Quoted in VO, 20 October, p. 460, from L'Internazionale, 11 September.

86 Rosmer to Monatte, 2 October.

8720 October, pp. 449,456, 458-59. Note that in its Zurich conference in September 1913 the ISNTUC changed its name to the International Federation of Trade Unions. G. Dumoulin attended the conference on behalf of the CGT. In reporting the conference, 
But the hope expressed by La Vie Ouvrière before the congress that once it had been held its participants would appreciate French arguments was not fulfilled. Although the dangers of schisms, especially in France, had played an important role in the discussions of the congress, few delegates accepted the view that the CGT had a serious role to play in the IFTU. In the wake of the debate surrounding the congress, Albert Jensen expressed the majority view when he declared that he found the participation of the CGT in the IFTU a "more than comic situation" and French arguments in favour of this tactic "exceedingly lame". Its presence there, despite its own claims, did nothing to spread syndicalism:

it is not from the top downwards [via the IFTU] that this transformation takes place, but the opposite, from the bottom upwards by the continuous revolutionizing of the masses. The CGT as an organization has no influence in this direction; it is not the CGT which wins the international masses for syndicalism. On the contrary, its relative organizational weakness is often a serious hindrance to the spreading of our ideas in other countries. No, it is the syndicalist view itself which is so strongly constructed that it draws the masses to itself; and it is due to the advance of the revolutionary militants in their respective countries that these ideas get to be known and make victorious progress, and not at all due to the CGT, much less to its remaining in the old International. 88

Despite regret that more items on the agenda had not been dealt with, despite the difficulties of language and personality, the existence of which they made little effort to conceal in their respective reports, the general consensus among those involved in the congress, aside from De Ambris, was that it had achieved significant results. Cornelissen asserted that revolutionary unionists everywhere could be satisfied with its work. Because the large British and American unions were too conservative to adopt a less apathetic existence, and the centralist unions of Europe too permeated with social democracy, it had fallen to the syndicalists to organize an international workers' assembly. If they could retain their lead for a few years, their influence on the development of a workers' International

Dumoulin did not mention the London congress, but alluded to it, as well as to the domestic pressures which kept the CGT in the IFTU: "Désespérer, aller ailleurs, compromettre notre unité nationale parce que le Secrétariat de Berlin est réformiste! Ce serait gravement nous tromper, ce serait faire fausse route et laisser sans contrepoids les idées qui ne sont pas les nôtres. Dans cette Internationale, notre syndicalisme révolutionnaire ne peut pas se diminuer, il ne peut que pénétrer chez les autres. [ . . ] tout en constatant que le Secrétariat international ne correspond pas à nos idées, je suis revenu de la Suisse avec cette forte impression que notre C.G.T. y était à sa place". La Voix du Peuple, 5-12 October.

88 Syndikalisten, Julnummer. 
would be great. ${ }^{89}$ Attention was directed to the observation in Kater's presidential address that, as a first congress, it could be counted a success if the questions of theory and tactics and international organization were dealt with. "The congress has accomplished this and more cannot in fairness be expected of it", Die Einigkeit observed.$^{90}$ As the declaration of principles garnered the criticism of its natural opponents, it was hailed by its supporters. The congress, Negre asserted, "has marked again with its decisions the true paths toward proletarian emancipation". Bowman declared that the formulation of the "historic declaration of principles" alone justified the existence of the congress. And while the German social democrats were dismissing its "trite phrases", in Sweden Gustav Sjöström, editor of Syndikalisten, was praising the declaration for having delivered a clear exposition of the economic content of syndicalism, which the "toothless, political, social-democratic old market women have sought to falsify for the sake of their own worthless wares". 91

But it was the establishment of the Information Bureau or committee of relations to which most supporters pointed as the major achievement of the congress; it was its "most important success" for Bernardo, and of preeminent significance for Negre, for it meant that "in future the scattered revolutionary elements of the different countries will not struggle in vain". For some of them the long-discussed distinction between a bureau or committee of relations and an International was immaterial, a linguistic ploy. Thus Duque, who also saw the creation of the Amsterdam Bureau as the item of central importance in the work of the congress, declared: "Pour nous, Espagnols, en raison de notre conception de l'organisation et de notre esprit décentralisateur, contraire à tout fonctionnarisme et bureaucratisme professionnels, le fait de nommer un comité d'entente [. . . ] constitue un nouvel organisme en face du secrétariat de Berlin." Duque asserted that the Argentinian, Dutch and German delegations shared the Spanish view that "l'internationale révolutionnaire a été constituée". And Jensen of Sweden observed that "whether one calls this Bureau a Correspondence Bureau, a Unity Committee, or whatever, it is nevertheless a fact that the new Red International is a reality", and added: "If one can avoid a fatal split in France through a difference in name, then all is well."92

89 Bulletin, 12 October and 2 November.

9018 October.

91 Negre in Solidaridad Obrera, 9 October; Bowman in SAN, December; Sjöström in Syndikalisten, 8 November.

92 Bernardo in La Protesta, 5 November; Negre in Solidaridad Obrera, 16 October; Duque in Les Temps Nouveaux, 18 October; Jensen in Syndikalisten, 18 October. 
Though the creation of the Information Bureau was warmly received by most non-French syndicalists, they were under few illusions about the difficulty and immensity of the task that lay ahead of it. Thus Jensen again: "May we hope for the best from the newly-born one. And may we not exaggerate. The child is no world power, simply because it has been born, but it can become one if we all strongly will it, for all the conditions exist [for its growth]. If we will it, we shall conquer, although after many a bitter struggle." Similarly, for Negre, the Amsterdam Bureau was "a potent organization of world solidarity", but one which required further strenuous efforts to actualize its potential. If the syndicalists of the various countries worked with all their energies toward this goal, "the surpassing force of revolutionary syndicalism will be demonstrated in incontrovertible form". For the Germans of the FVDG, the congress had erected the scaffolding for the revolutionary class struggle; it was up to the syndicalist militants to complete the structure. ${ }^{93}$

Nor to the Argentinians of the FORA had the congress been a failure, quite the reverse: they considered it a large success and were confident that from the work it had initiated would come a new, "purely worker and antistatist" International. The congress was doubly rewarding for $L a$ Protesta, for it was not only an important step forward internationally, but it also constituted a great moral and doctrinal victory over the FORA's domestic rival, the Regional Workers' Confederation. For the latter had given its mandate to De Ambris, and in the absence of the large reformist union organizations (amongst which La Protesta included the CGT), De Ambris alone had represented the reformist tendency at the congress. In the end De Ambris had had "to bite the dust of a complete rout". But if this were not enough, La Protesta had even more startling news with which to mark its victory over its domestic opponent. Because it was late in reporting the congress, it was able to include the disturbing news that within a month of his appearance there, De Ambris had been elected to the Italian parliament. Small wonder, La Protesta implied, that against the clearly antistatist interpretation supported by the FORA at the congress, De Ambris, "who was on the eve of being elected a deputy and by consequence of forming part of the state, struggled with real energy". ${ }^{94}$

In Amsterdam the Dutch began the work of the International Bureau. A provisional committee issued over Markmann's signature a call for the syndicalist organizations to adhere: "Forward on behalf of revolutionary

93 Jensen in Syndikalisten, 18 October; Negre in Solidaridad Obrera, 9 and 16 October; the FVDG in Die Einigkeit, 18 October.

${ }_{94}$ La Protesta, 8 November. 
and international syndicalism. We have full confidence in being supported by the revolutionary syndicalists in all countries." 95 In the early months of 1914 a permanent committee headed by van Erkel and Markmann was established. As the Bureau prepared to launch its bulletin, Cornelissen terminated his own Bulletin on March 22, and offered his assistance to that of the Bureau. The first issue of the Bureau's publication, which took the same name as Cornelissen's Bulletin International du Mouvement Syndicaliste, appeared with the date 1-5 April 1914. The editorial duties remained primarily in Cornelissen's hands. ${ }^{96}$ In introducing the first issue, Markmann spoke with confidence in the ability of the Bulletin to overcome the inevitable difficulties attending all new works and of its enabling the Bureau "to continue in an ever more energetic and systematic fashion the propaganda of the principles of syndicalism and of our tactic of revolutionary struggle within the international workers' movement". But the new Bulletin was to be short-lived. The first issue offered reports from Germany, Portugal and England. The last report of the seventeenth and last issue, appearing at the end of July, dealt with the Balkans. ${ }^{97}$

\section{IX}

The significance of the 1913 congress has been little remarked and the virtual silence with which it has been passed over broken only occasionally by an acknowledgement of its existence. ${ }^{98}$ Yet it bore a significance which should not be overlooked and which relates to the post- as well as to the pre-war period. In the first place, the congress served to underline the degree to which syndicalism had become an international movement by 1913. De Ambris's earlier desire that the congress become an affirmation of syndicalism as an international and not merely a French "mode" was indeed realized, even if in a manner which De Ambris could not fully commend. Moreover, the form which this affirmation took is instructive. As the first international articulation of the principles of syndicalism, the declaration unanimously endorsed in London indicated clearly that its formulators viewed the libertarian elements in the syndicalist matrix not simply as incidental, but as integral components of the syndicalist creed. This is especially evident in the case of antistatism. The London decla-

95 Bulletin, 16 November.

96 Cornelissen, "Strijd, lief en leed", p. 439.

97 Strictly speaking, there were eighteen issues. The eighteenth, dated 1 January 1915 , attributed the disappearance of the Bulletin to wartime conditions.

98 An exception is Christian Gras, who discusses the congress in his Alfred Rosmer, op. cit,, pp. 86-97. But Gras is concerned above all with Rosmer's career and is content to accept Rosmer's account of the course and significance of the assembly. 
ration explicitly condemned the state and saw its destruction as much as an objective of syndicalism as the abolition of capitalist exploitation. Though the CGT professed the same goal, its 1906 Charte d'Amiens, by contrast, made no explicit reference to the state. To judge by the debate in London, the syndicalists assembled there would not have accepted the Charte d'Amiens, often considered the classical statement of revolutionary syndicalism, as an adequate expression of their viewpoint. And in fact the Charte was above all a document of compromise, a formula designed to shield organizational unity from the perils of ideological dissonance. As an attempt to bridge doctrinal differences and neutralize the effects of the ideological dissent which characterized the history of the CGT, the Charte may well be considered a classical expression of French syndicalism. But in the absence of the CGT, the major syndicalist organizations represented in London were organizationally independent of the reformist and political elements in the labour movements of their respective countries. They spoke for the revolutionary syndicalists alone. If the Charte d'Amiens is the classical expression of pre-war French syndicalism, the London declaration may equally be considered the classical expression of pre-war syndicalism beyond French borders. And the London declaration demonstrated the degree to which the syndicalists of Europe viewed syndicalism as being essentially anarcho-syndicalism. This doctrinal determination had its corollary ten years later when the International Working Men's Association was founded. The 1922-23 founding congress made the anarcho-syndicalist foundation of the new International explicit. The IWMA was fully justified in looking back upon the London congress as the pioneering effort of syndicalist internationalism.

In organizational terms, the congress had been a step towards a Syndicalist International, though a faltering one. The syndicalists gathered in London took the internationalism of their creed seriously and they insisted that labour internationalism return to the revolutionism which had attended its birth fifty years earlier. The ISNTUC, wedded to reformism and the Second International, could not fulfil this task, and few delegates accepted the arguments of the CGT in this respect. Nor did any of the independent syndicalist union organizations of Europe accept the argument of the CGT that the task of syndicalism outside France was the permeation of existing reformist unions. The London congress nevertheless demonstrated considerable solicitude for the CGT. The delicate internal situation in France was discussed with sympathy in London, and with far more candour than it had been in the pages of La Vie Ouvrière. The decision to delay the establishment of a Syndicalist Secretariat and to settle temporarily for the creation of an Information Bureau owed more to 
the desire to avoid a split in French labour than to any other factor, though the CGT felt unable to acknowledge the solicitude and deference shown it. The compromise solution on the question of international organization, moreover, contributed to the note of frustration woven through the reports of some of the congress supporters. The need for legitimization and selfassertion had not been fully satisfied. Though they could describe the congress as an advance for the syndicalist movement, they recognized that it had not been a full, but at most a half, step forward.

Those delegates who predicted that the split in France would eventually come were correct, though it came in circumstances which they scarcely could have foreseen. In the wake of war and revolution, moderates and revolutionaries found cohabitation in a single CGT impossible, and the international question played a crucial role in the rupture which followed. In international policy, however, neither group would carry the apoliticism of their pre-war creed to its logical conclusion, the former taking refuge in the resuscitated, reformist IFTU, the latter in the highly politicized Profintern, the trade-union appendage of the Communist International. It would remain to the non-French syndicalists to pursue the establishment of a revolutionary trade-union International free of political tutelage. The debate over the nature of the Comintern and the Profintern and the question of international allegiance would preoccupy the syndicalists of Europe in the post-war period. Events demonstrated that the issues surrounding the 1913 congress served as a prelude to those which predominated in post-war debates on labour internationalism. The syndicalists, in advance of the Bolsheviks, had proclaimed the need for a new and genuinely revolutionary International. The Bolshevik Revolution and the emergence of communist internationalism, so far from provoking the creation of a Syndicalist International, actually acted to delay it, if also to accentuate its libertarian basis. The London congress had served notice of the necessity perceived by many syndicalists that they chart their own course, nationally and internationally. But ten years passed before the syndicalist flotilla assembled and set sail in international waters. 